FILOLOGIJA 74, Zagreb 2020.

UDK 811.163.42'36-122

DOI https://dx.doi.org/10.21857/yq32oh2ew9

Pregledni rad

Rukopis primljen 27. V. 2019.

Prihvaćen za tisak 1. VII. 2019.

Martina Kramarić

Institut za hrvatski jezik i jezikoslovlje

Republike Austrije 16, HR-10000 Zagreb

mkramar@ihjj.hr

\title{
PRILOG ISTRAŽIVANJU HRVATSKE SASTAVNICE RUKOPISNE GRAMATIKE PRINCIPI DELLA GRAMMATICA [...] GRAMMATICA PRIMA IN LINGUA SLAVA, ITALIANA ET LATINA GAŠPARA VINJALIĆA ${ }^{1}$
}

U radu se donosi opis neobjavljene i nedovoljno poznate rukopisne gramatike Principi della grammatica [...] Grammatica prima in lingua slava, italiana et latina franjevca Gašpara Vinjalića. Gramatika je trojezična, latinska, talijanska i hrvatska, a sačuvana je u prijepisu nepoznata autora iz 1809. godine. Pretpostavlja se da je nastala sredinom 18. stoljeća. Pisana je prema latinskome modelu, odnosno u gramatici je latinski polazni jezik za koji se primjeri donose i na hrvatskome jeziku. Stoga je ovaj rad posvećen opisu hrvatske sastavnice u gramatici, koja je raznonarječna, i opisu Vinjalićeva hrvatskoga jezika na fonološkoj i morfološkoj razini. Posebnu pozornost obratit ćemo na obradu imenskih riječi u gramatici te na moguće utjecaje književnoga i razgovornoga hrvatskoga jezika na autora. Gramatiku također dovodimo u kontekst s onodobnom gramatikološkom tradicijom.

1 Rukopis ovoga članka poslan je za objavljivanje u svibnju 2019. godine, a u međuvremenu je objavljen članak autora Vinka Kovačića Trojezična gramatika fra Gašpara Vinjalića: struktura i usporedba (Poglavlja iz romanske filologije: u čast akademiku Augustu Kovačecu o njegovu 80. rođendanu. 2018. Ur. Lanović, Nina; Maslina Ljubičić; Maša Musulin; Petar Radosavljević; Sanja Šoštarić. FF press. Zagreb. 303-317). Kako taj članak nije bio objavljen u vrijeme rada na ovome članku (iako nosi 2018. kao godinu tiskanja) te kako za njega nismo imali saznanja, moguće je da donosimo neke iste spoznaje iako se njime nismo služili, ali i da taj članak ima neke nove spoznaje, posebice u kodikološkome opisu rukopisa gramatike, jer je autor toga članka imao priliku konzultirati rukopis uživo. 
Martina Kramarić: Prilog istraživanju hrvatske sastavnice rukopisne gramatike Principi...

FILOLOGIJA 74(2020), 17-48

Neobjavljenu i usudili bismo se reći malo poznatu rukopisnu trojezičnu gramatiku Principi della grammatica [...] Grammatica prima in lingua sla$v a$, italiana et latina ${ }^{2}$ napisao je Gašpar Vinjalić sredinom 18. stoljeća. Sačuvani rukopisni primjerak čuva se u Arhivu Franjevačkoga samostana u Sinju ${ }^{3}$ s navedenom 1809. godinom, dakle, nakon autorove smrti. ${ }^{4}$ Podatci o vremenu nastanka izvornoga teksta nisu navedeni, pa zaključujemo kako je riječ o prijepisu gramatike nepoznata prepisivača. O samoj gramatici skoro da i nema zapisa u dosadašnjoj tradiciji proučavanja hrvatskih predstandardnih gramatika, ${ }^{5}$ sam autor Gašpar Vinjalić, franjevac i visoki crkveni dužnosnik, poznatiji je kao povjesničar i arheolog, autor djela u trima svescima Povijesno-kronološki pregled najvažnijih događanja o Ilirima i Slavenima u Dalmaciji, Hrvatskoj i Bosni (Compendio istorico e cronologico delle cose più memorabili occorse agli Illiri e Slavi in Dalmazia, Croazia e Bosna). ${ }^{6}$ Gašpar Vinjalić rođen je u Zadru, ali je poznato da je nakon zaređenja kod "bosanskih fratara" u samostanu Visovac neko vrijeme proveo i »kao gojenac u Provinciji Bosni Srebrenoj« (Gulin 2011:398). ${ }^{7}$ Službovao je kao franjevački župnik i učitelj redovničke mladeži u Šibeniku i Kninu, a bio je i predstojnik franjevačkoga samostana u Šibeniku i definitor fra-

2 Puni naslov gramatike glasi Principi della grammatica ad uso de Slavi che desiderano esser Religiosi con quali apprenderano nell'istesso tempo la Lingua Latina ed Italiana, servirà anco agli Italiani per apprender la Lingua Slava. Opera di Fra Gasparo Vignalich ex Diffinitor dell'Osservante Provinzia dell Santissimo Redentor in Dalmazia. Grammatica prima in lingua slava, italiana et latina. Za prijevod i tumačenje talijanskoga metateksta izrazito smo zahvalni dr. sc. Ivani Lovrić Jović. Citate na talijanskome jeziku navodimo u izvornoj grafiji i pravopisu. Autorica je transkripcije hrvatskoga teksta u gramatici za sve primjere Martina Kramarić.

3 Biblioteka Arhiva Franjevačkoga samostana u Sinju još je u postupku sređivanja, pa je gramatici dodijeljena signatura prema položaju u knjižnici I./2. Zapisana na koricama rukopisa u gornjemu lijevom kutu.

4 Gašpar Vinjalić rođen je 1707. u Zadru, a preminuo je 1781. u Visovcu.

5 Gramatika se pojavljuje samo na popisima hrvatskih predstandardnih gramatika, kao onoga Zagrebačke slavističke škole (vidi popis hrvatskih gramatika Zagrebačke slavističke škole (http://www.hrvatskiplus.org/article.php?id=1760Enaslov=hrvatskegramatike, pristupljeno 12. travnja 2019.), ali ne na svim. Primjerice, Ham je ne navodi u svojemu popisu Kronološki pregled hrvatskih gramatika (Ham 2006). Kratku napomenu o tome da je to trojezična gramatika navodi Jernej u svojemu istraživanju talijanskih gramatika pisanih na hrvatskome jeziku (Jernej 1981:176-177).

6 Prva dva sveska tiskana su u Mletcima 1775. godine pod naslovom Svjetovna i crkvena povijest Dalmacije, Hrvatske i Bosne (Storia civile ed ecclesiastica della Dalmazia, Croazia e Bosna. In libri dodici compendiata), i zajedno obuhvaćaju povijesni pregled do 1520. godine, dok je treći svezak objavljen tek 2010. godine (Kapitanović 2010). (http:// www.enciklopedija.hr/natuknica.aspx?id=64749, pristupljeno 12. travnja 2019.).

7 Taj je podatak važan i zbog opisa hrvatskoga jezika u njegovoj gramatici. 
njevačkoga reda. ${ }^{8}$

U ovome radu donosimo formalni i sadržajni opis Vinjalićeve gramatike te se fokusiramo na hrvatsku jezičnu sastavnicu gramatike. Posebice ćemo pozornost obratiti na grafiju kojom je pisana te na jezičnu (fonološku) analizu hrvatskoga jezika u gramatici, onakvoga kako ga je Vinjalić tek sažeto opisao, ali i potkrijepio primjerima i popisima riječi (priloga, prijedloga i glagola) na kraju gramatike. Također ćemo se osvrnuti na njegov opis imenskih riječi iako zauzimaju opsegom manji dio gramatike. Dosta opširan i složen opis glagolskoga sustava, konjugacije i glagolskih vremena, ostavit ćemo za neku drugu priliku jer taj opis zahtijeva zasebno istraživanje i zaseban rad.

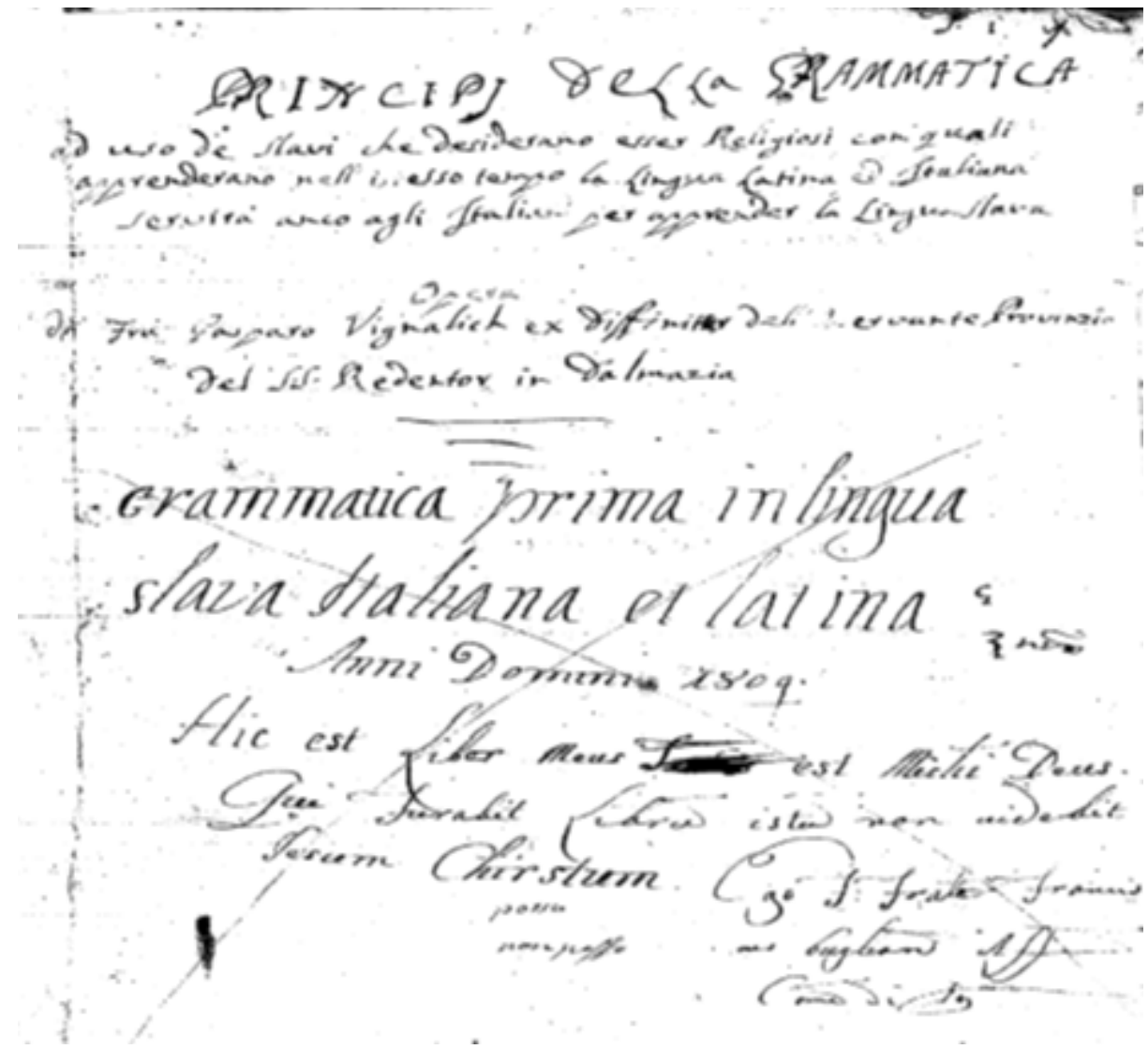

Prilog 1. Snimka naslovne stranice rukopisne Vinjalićeve gramatike

8 Tako je i potpisan na prvoj stranici rukopisne gramatike Opera di Fra Gasparo Vignalich ex Diffinitur dell' Osservante Provinzia dell Santissimo Redentor in Dalmazia. 
Martina Kramarić: Prilog istraživanju hrvatske sastavnice rukopisne gramatike Principi...

FILOLOGIJA 74(2020), 17-48

\section{Opis gramatike}

Vinjalićeva gramatika Principi della grammatica [...] Grammatica prima in lingua slava, italiana et latina trojezična je u smislu da se u gramatici izmjenjuju latinski, talijanski i hrvatski jezik (tim redoslijedom). Gramatička pravila i upute autor piše talijanskim jezikom, te tek iznimno na samome početku na hrvatskome jeziku, a odnose se na sva tri navedena jezika. Tako će se među pravilima i opisu navoditi pravila i za hrvatski jezik, iako sažetija i kraća, i samo rjeđe pisana hrvatskim jezikom. ${ }^{9}$ Primjeri su pisani svim trima jezicima, a hrvatski je jezik posljednji u nizu navođenja primjera nakon latinskoga i talijanskoga.

Gramatika je uz Šitovićevu ${ }^{10}$ i Babićevu ${ }^{11}$ jedna $u$ nizu pisanih za franjevačke škole u 18. st., ali je ujedno prva takva trojezična gramatika za franjevačke škole i gramatika kojoj je jedna od sastavnica hrvatski jezik. Sam autor na naslovnici navodi razloge pisanja: gramatika je namijenjena podučavanju redovničke mladeži hrvatskomu jeziku, ali istovremeno i latinskomu i talijanskomu jeziku. Također će pomoći Talijanima u savladavanju slavenskoga (hrvatskoga) jezika. Poslije u uvodnome dijelu Vinjalić ponavlja kako je namijenjena »za uprav besiditi i pisati« (Vinjalić 1809:2). ${ }^{12}$

Međutim, unatoč svojoj namjeni, a ona je, kako na dvama mjestima piše, namijenjena za pripravnike u franjevačkoj školi, odnosno redovničku mladež, gramatika nije odjeknula dalje od samostanskih zidova, vjerojatno stoga što nije bila tiskana. ${ }^{13}$

Iako je gramatika pisana s namjenom podučavanja hrvatskomu jeziku, ona zapravo i nije gramatika hrvatskoga jezika, kako je to već potvrđeno s brojnim gramatikama koje se u popisima najranijih hrvatskih gramatika

\footnotetext{
9 Primjerice, definicija gramatike i pravilo o deklinaciji imenica.

10 Riječ je o gramatici Grammatica Latino-Illyrica. Venecija, 1713.

11 Riječ je o gramatici Prima grammaticae institutio pro tyronibus illyricis accomodata. Venecija, 1712 .

12 To je uostalom i tumačenje značenja riječi gramatika koje se u potpunosti podudara sa Šitovićevim tumačenjem, također autorom franjevačke gramatike Grammatica Latino-Illyrica (1713.): »Gramatika jest zanat za uprav besiditi i pisati« (Vinjalić 1809:2). (Stolac 2009:115).

13 Vicko Kapitanović, priređivač Vinjalićeva djela Kratki povijesni i kronološki pregled zbivanja koja su se dogodila Slavenima u Dalmaciji, Hrvatskoj i Bosni 1514.-1769., piše kako je Vinjalićeva gramatika »prva franjevačka gramatika priređena za franjevačke škole, iako se vjerojatno malo rabila« (Gulin 2011:398). Moramo korigirati autorov navod te napisati kako ovo nije prva franjevačka gramatika, ali jest prva trojezična franjevačka gramatika. Vidi popis hrvatskih gramatika Zagrebačke slavističke škole (http://www.hrvatskiplus.org/article.php?id=1760Enaslov=hrvatske-gramatike, pristupljeno 12. travnja 2019.).
} 
Martina Kramarić: Prilog istraživanju hrvatske sastavnice rukopisne gramatike Principi... FILOLOGIJA 74(2020), 17-48

navode kao hrvatske gramatike. ${ }^{14} \mathrm{U}$ njihovu kao i ovom slučaju, a prva je takva gramatika već i Kašićeva gramatika, ${ }^{15}$ latinski je jezik polazni jezik i jezik koji se u gramatici opisuje, a primjeri su dani na hrvatskome jeziku uz latinski i talijanski jezik. U tim se okolnostima opis i primjeri na hrvatskome jeziku prilagođavaju latinskomu jezičnom sustavu ${ }^{16}$ ili talijanskomu jezičnom sustavu. ${ }^{17}$ Hrvatski se jezik, dakle, u gramatici predstavlja modelom drugoga jezika, u ovome slučaju latinskoga, kao što je to slučaj i s prvom gramatikom hrvatskoga jezika. ${ }^{18}$

Slika o hrvatskome jeziku koji autor opisuje konstruira se stoga djelomično ${ }^{19}$ preko primjera, ali i popisa riječi koje Vinjalić donosi na kraju gramatike (priloga, prijedloga, veznika, glagola te rijetkih sintagma ili dijelova rečenice). Unutar se same gramatike, dakle, nalaze i popisi riječi, u dije-

14 O problemu mogu li se uopće takve gramatike koje su pisane prema modelu stranoga jezika uvrstiti u popis hrvatskih gramatika vidi u Vlastelić (2007:251-252). Sličan komentar iznosi i Demo, koji piše kako su gramatike kao Babićeva i Šitovićeva »(...) spomenici hrvatskoga jezika (...), ali ih moramo smjestiti u tradiciju naših latinskih gramatika ili, možda bolje reći, u tradiciju naših udžbenika latinskog jezika (koje valja razlikovati od onoga što danas nazivamo deskriptivnom gramatikom, budući da su iscrpnost, dosljedna znanstvena preciznost i didaktičnost kriteriji koji se često međusobno isključuju) (Demo 2004:46-47).

Vidi popis hrvatskih gramatika Zagrebačke slavističke škole (http://wwww.hrvatskiplus.org/article.php?id=1760Enaslov=hrvatske-gramatike, pristupljeno 12. travnja 2019.). U ovome radu osvrtat ćemo se samo na gramatike koje u sastavu imaju hrvatski, latinski ili talijanski jezik, tj. one će nam služiti za usporedbu, dok se na kajkavske i na gramatike koje u svojemu sastavu imaju njemački jezik nećemo osvrtati.

15 Institutionum linguae Illyricae libri duo. Rim, 1604.

16 Primjerice, u opisu deklinacije navedeni su padeži prema latinskoj paradigmi, nominativ, genitiv, dativ, akuzativ, vokativ i ablativ. Također, $u$ popisu prijedloga $\mathrm{u}$ odlomku Rudimenta navode se prijedlozi koji idu uz dativ, akuzativ i ablativ, ali prema latinskome jeziku, dok se na hrvatski jezik isti prijedlozi samo prevode.

17 U opisu glagola navodi kako će pokazati da se hrvatskim jezikom mogu izreći talijanski konjunktivi (Vinjalić 1809:42). Također, prema talijanskome jeziku tumači uporabu enklitika za genitiv i dativ osobnih zamjenica on, ona, ono, te ih i prema talijanskome jeziku zapisuje zajedno s glagolom: predlaže pisanje recimu umj. reci njemu, ja ljubimga umj. ja ljubim njega. (isto:26).

18 »Predstavljanje jednoga jezika po modelima drugoga uvijek implicira mogućnost da opis bude nepotpun i nesavršen, katkad nepotrebno kompliciran, što se dogodilo i Kašiću « (Gabrić-Bagarić 2002:393). U citatu istaknuta »nepotrebna kompliciranost « u Vinjalićevu slučaju posebice se očituje u poglavljima o glagolima, koja se protežu od 30. do 171. stranice, u kojima je Vinjalić pokušao pokazati kako se hrvatskim jezikom mogu izreći konjunktivne konstrukcije na talijanskome jeziku. Među glagolskim oblicima navode se i supin (ne u današnjemu značenju), participi, gerund, što je sve uobičajeno za hrvatske gramatike koje prate latinski model.

19 Ističemo riječ djelomično jer se u gramatici ne navode primjeri slobodnoga jezika (dulje sintagme ili rečenice) u kojima bi prikaz hrvatskoga jezika bio potpuniji. 
Martina Kramarić: Prilog istraživanju hrvatske sastavnice rukopisne gramatike Principi... FILOLOGIJA 74(2020), 17-48

lu nazvanome Rudimenta, i to prema vrstama riječi: prijedlozi (s podjelom prema padežima), veznici, prilozi, glagoli, koji se također piše za redovničku mladež »Adverbia ordine Alphabetico pro Tyronibus« (od 186. str.). U popisu se navodi prvo latinski pa talijanski i zatim hrvatski jezik, koji je ujedno i ciljni jezik, pa se katkad navodi i nekoliko sinonima uz hrvatski prijevod, najčešće raznonarječnih inačica.

Hrvatski se jezik naziva »lingua Slava«, a samo se jednom spominje naziv Croato. U gramatici je prikazan hrvatski jezik utemeljen na štokavskoj osnovici ikavskoga i ijekavskoga govora s elementima čakavskoga. Primjeri su iz dalmatinsko-dubrovačkoga govora i dalmatinsko-dubrovačke književnosti te djelomično bosanske franjevačke književnosti. U nizu različitih značajka primjetan je i utjecaj narodnoga jezika.

U gramatici se donosi i hrvatsko gramatičko nazivlje, doduše ne za sve gramatičke kategorije, ali u tome području ova gramatika slijedi dvije Mikaljine gramatike, ${ }^{20}$ od kojih se mogu pratiti jezikoslovni termini zapisani i na hrvatskome jeziku, te Šitovićevu gramatiku Grammatica Latino-Illyrica (1713.). ${ }^{21}$

Kako to autor otkriva na više mjesta uputnicama »vide Emmanuel«,22 gramatika se naslanja na poznatu gramatiku portugalskoga isusovca Manuela Álvaresa (De Institutione Grammatica Libri Tres, 1752.), kako je to inače slučaj s hrvatskim povijesnim gramatikama, pa i franjevačkim gramatikama (Perić Gavrančić 2015:58). ${ }^{23}$ Na 42. str. rukopisne gramatike Vinjalić piše ${ }^{24}$ kako bi se Álvaresovom gramatikom trebali služiti svi koji žele pravilno naučiti latinski jezik. Česte upute na njegovu gramatiku autor daje zbog sažetosti i ekonomičnosti (»da mu gramatika ne bude skupa«, a to

20 To su gramatika latinskoga jezika objašnjena hrvatskim De institutione grammatica pro Illyricis accomodata (Rim, 1637.) te gramatika talijanskoga jezika u kojoj je metajezik hrvatski Grammatika talijanska ukratko, tiskana u rječniku Blago jezika slovinskoga (Loreto, 1649. - Ancona, 1651.).

21 O tome je više riječi bilo u izlaganju Jezikoslovno nazivlje u hrvatskim franjevačkim gramatikama 18. stoljeća, koje je izloženo na Hrvatskome slavističkom kongresu 2019. u rujnu u Šibeniku.

22 Primjerice, »Ed altre simili particelle, come si puo vedere nella Gramatica d’Emmanuele« (Vinjalić 1809:42).

23 D. Raguž (1980-81:101) u kontekstu prerada gramatike isusovca Álvaresa piše kako su prve prerade u 18. stoljeću pisali upravo franjevci.

24 »Il mio volume sarebbe di troppa spesa a mettere tutte le regole, con sui esempi, percio li studenti abbino seco la Gramatica Emmanuel, che costa poco, dalla quale potranno apprender tutto quello che vi vole per parlar retamente Latino. Questa mia solo deve servir per li principianti, e per gli Italiani che desiderano parlar in Slavo.« (Vinjalić 1809:42). 
znači da je bilo u planu tiskanje), dok je Álvaresova gramatika »jeftina i pristupačna (Vinjalić 1809:42).

Rukopis gramatike obaseže ukupno 327 stranica. ${ }^{25}$ Gramatika je nabavljena kao preslika iz Franjevačkoga samostana u Sinju, ${ }^{26}$ a neke su njezine rukopisne stranice oštećene i slabo čitljive, i to 6., 7. i 8. stranica rukopisa gdje se tumače članovi, opis konjugacije glagola i deklinacija imenica, te poneke stranice na kraju rječnika s popisom glagola. Gramatički je dio zapisan do 273. stranice. Dio od 274. do 278. stranice je prazan, a nedostaju 279. i 280. stranica. ${ }^{27}$ Nakon gramatičkoga dijela i dijela u kojemu je naveden popis riječi nalazi se dodatak u kojemu su zemljopisno opisane Dalmacija i Bosna i Hercegovina Geografia di Dalmazia secondo la divisione delle Provinzie Romane fatta da Cesare Ottaviano Augusto (od 281. stranice). Taj dio također funkcionira kao popis i bogat izvor onomastičke građe pisane trima jezicima s hrvatskim i bosanskim imenima rijeka, jezera, planina, otoka, pa i šire, uz kraća tumačenja na talijanskome jeziku. Od 295. stranice slijedi abecedni indeks (Indice) s popisom povijesnih ličnosti i događaja povezanih s gore navedenim prostorom, odnosno s današnjom Hrvatskom i Bosnom i Hercegovinom, zapisan samo na talijanskome jeziku. Taj je popis naveden u dva dijela. Svakako se zemljopisnim i povijesnim dodatkom namjena ove gramatike širi, te ona bogatom onomastičkom građom, ali i s dosta povijesnih podataka može biti zanimljiva istraživačima različitih znanstvenih disciplina.

\section{Sastav gramatike}

Svoju opširnu gramatiku autor je podijelio na 4 dijela: »slovo, sastavak, rečenje, govorenje«(Vinjalić 1809:3). To je u praksi provedeno na način da je prvi dio posvećen deklinabilnim riječima, imenicama, pridjevima i zamjenicama, nakon čega slijedi izrazito detaljno razrađen dio o konjugaciji glagola podijeljen prema podjeli glagola na vrste, naravno prema latin-

25 Stranice rukopisne gramatike obrojčane su u gornjem desnom ili lijevom kutu, ovisno o stranici rukopisa.

26 Gramatika je pribavljena za potrebe projekta Dopreporodne hrvatske gramatike, koji se provodi u Institutu za hrvatski jezik i jezikoslovlje, 2013. godine, tako da je na prijedlog kustosa Arhiva Franjevačkoga samostana u Sinju fra Mirka Marića donesena $\mathrm{u}$ Zagreb te je u Zagrebu napravljena njezina digitalna preslika. Za potrebe ovoga članka korištena je isključivo ta preslika, a prema kustosu fra Mirku Mariću preslika rukopisa vjerno odražava stanje rukopisa koji je na nekim mjestima oštećen. Srdačno zahvaljujemo kustosu fra Mirku Mariću i Arhivu Franjevačkoga samostana u Sinju na dopuštenju da se napravi preslika rukopisne gramatike.

27 U lijevom gornjem kutu na 281. stranici stoji poruka unesena pri naknadnome uvezivanju »Fale arci $18-28 \ll$. 
Martina Kramarić: Prilog istraživanju hrvatske sastavnice rukopisne gramatike Principi...

FILOLOGIJA 74(2020), 17-48

skome modelu. Posljednji jezični dio gramatike Rudimenta bavi se prijedlozima, prilozima i veznicima. Vinjalić tako donosi popis prijedloga koji idu uz određeni padež, ali i tu se ravna latinskim jezikom kao polaznim, te su navedeni hrvatski prijedlozi samo prijevodi latinskih inačica koji su navedeni prema slaganju s padežom u latinskome jeziku. Slijedi popis prijedloga, nekih latinskih izreka koje prevodi na hrvatski jezik te popis veznika koje dijeli na više vrsta te donosi hrvatsko nazivlje za veznike. ${ }^{28}$

Iako je i u popisu veznika latinski zapravo polazni jezik, a hrvatski su veznici prijevodi latinskih konstrukcija, ne uočavamo neke razlike u uporabi s obzirom na stanje u standardnome hrvatskom jeziku. Od 186. do 230. stranice donosi se popis atributa kao dio "govorenja (Adverbia ordine Alphabetico pro Tyronibus), ${ }^{29}$ a misli se na priložne oznake, također prema latinskome kao polaznome jeziku. Taj je dio gramatike izuzetno važan kao izvor za proučavanje hrvatskoga jezika koji opisuje Vinjalić, posebice leksika, jer su hrvatski primjeri većinom zabilježeni s dvama ili trima sinonimnim riječima.

Prije uvodnoga dijela s tumačenjem gramatike navodi se kratak osvrt o povijesti slavenskoga jezika i o izumu slavenskoga pisma od Svete braće.

Što se tiče jezičnoga dijela, gramatika je podijeljena na 16 poglavlja iako ta poglavlja ne prate uvijek realno podjelu obrađenoga gradiva. Poglavlja su označena rimskim rednim brojem i latinskom riječju Caput ili u slučaju prvoga poglavlja talijanskim Capitola. Uvodno poglavlje naziva Capitolo Proemiale $(2-8)^{30}$ i u njemu donosi definicije osnovnih gramatičkih pojmova pisane na trima jezicima i navodi razlike između jezika u deklinaciji imenica. Nakon tih napomena i napomene o uporabi članova u talijanskome jeziku (Articoli), slijedi pojašnjenje da u latinskome jeziku postoje četiri konjugacije, a u talijanskome i hrvatskome jeziku tri. Zatim slijede: I. poglavlje (8-16); II. poglavlje (16-22) Nomina adiectiva et anomala; III. poglavlje (22-30) Pronominum Declinatio; IV. - X. poglavlje (30-124) Verborum Coniugatio; ${ }^{31}$ IX. poglavlje upućuje na Álvaresove komentare o konjugaciji glagola (105. str.); X. poglavlje Declinatio verbi deponentis (105-114);

28 »Sastavci dio jesu pristavljajući, dio podlagajući, a dio sridnji« (Vinjalić 1809:183-185). Navodi sljedeće vrste: sastavljajući ili vezajući, rastavljajući, protiveći, skupljajući ili iznoseći ili razložiti, uzrokljivi, ugovorljivi ili akovljivi, izpuneći.

29 U uputi na Álvaresovu gramatiku vidimo kako Vinjalić atribute smatra dijelom »govorenja « prema četirima dijelovima gramatike: »De accidentibus sive attributis partium Orationis vide Emmanuel« (Vinjalić 1809:186).

30 U zagradi su navedene stranice rukopisa na kojima se proteže poglavlje.

31 U svakom je poglavlju koje se odnosi na konjugaciju glagola pojašnjena jedna konjugacija: V. Prima Coniugatio (37-58); VI. Secunda Coniugatio (58-73); VII. Tertia Coniugatio (74-89); VIII. Quarta Coniugatio (89-105). 
Martina Kramarić: Prilog istraživanju hrvatske sastavnice rukopisne gramatike Principi... FILOLOGIJA 74(2020), 17-48

XI. poglavlje Declinatio Verbi Communis (114-124); XII. poglavlje (125-160) Verba Anomala; XIII. poglavlje (161-171) Verba Defectiva; XIV. (171-229) poglavlje Rudimenta Sive de octo partibus orationis; XV. poglavlje (230-232) Regole generali per le construzioni di tutte tre le lingue; XVI. poglavlje (233-273) De Verbi Attivi; (281-294) Geografia di Dalmazia; (295-326) Indice A. XVI. poglavlje nudi popis glagola koji imaju subjekt u nominativu, a objekt $\mathrm{u}$ akuzativu, odnosno prijelaznih glagola (De Verbi Attivi). XV. poglavlje donosi 14 sintaktičkih pravila za sva tri jezika (XV. o sintaksi Regole generali per le construzioni di tutte tre le lingue). Ona se odnose na sročnost (imenice odgovaraju pridjevu u rodu, broju i padežu), sročnost u uporabi odnosne zamjenice koji, izricanje posvojnosti, dopunu prijelaznih glagola u akuzati$\mathrm{vu}$, jednakost nominativa i akuzativa u muškome rodu u padežnoj paradigmi za neživo, o prijedlozima koji idu uz ablativ, kao prijedlog za (kupio sam knjigu za deset dinara), ablativu instrumentala bez prijedloga (pišem perom, jesam udaren šibikom) i ablativu s prijedlogom od (gnijem od muke, vel od bolesti). Dio pravila odnosi se samo na latinski i talijanski jezik, što još jednom potvrđuje činjenicu da ovo zapravo nije gramatika hrvatskoga jezika. Sintaktička normativna pravila rjeđe se navode i unutar drugih poglavlja, kao pravilo o nome possesivo (posvojnoj imenskoj riječi). ${ }^{32}$ Gramatika je važan izvor gramatičkoga nazivlja na hrvatskome jeziku.

U uvodnome poglavlju pri opisu temeljnih gramatičkih pojmova autor navodi dila govorenja (vrste riječi): ime ('imenica'), zajmenak ('zamjenica'), rič ('glagol'), dionstvo ('particip, pridjev'), pristavak ('prijedlog'), priričak ('prilog'), mejumetak ('uzvik') i sastavak ('veznik'). Odmah nakon navode se nazivi za padeže: imenujući ('nominativ'), porađujući ('genitiv'), dajući ('dativ'), osvađajući ('akuzativ'), zovući ('vokativ'), odnimajući ('ablativ'), 33 te napomena o sedmome i osmome padežu koji imaju Slaveni za razliku od latinskoga i talijanskoga jezika. U sintaktičkim uputama u XV. poglavlju sedmi padež naziva još i ablativ instrumentala.

32 To pravilo odnosi se na izražavanje posvojnosti i glasi: kada je imenska riječ navedena bez pridjeva, onda se mijenja genitiv imenice u posvojnu imensku riječ $(P e-$ trov otac, mater, vrime), ali kada ta posvojna imenska riječ uz sebe ima i pridjev, onda se i posvojnost izražava genitivom ili ablativom te imenske riječi (otac, mater, vrime svetoga Petra) (Vinjalić 1809:4-5). Posvojnost se dugo u hrvatskome jeziku izražavala genitivom imenica ili ličnih zamjenica, a taj će se utjecaj vidjeti poslije u gramatici pri obradi i određivanju ličnih i posvojnih zamjenica.

33 I nazivi za padeže isti su kao u Šitovićevoj gramatici, jedina je iznimka ablativ koji glasi odnosujući (Raguž 1980-1981:116). Raguž takve sličnosti ne tumači preuzimanjem gramatičke terminologije, »nego proširenošću tih termina u praksi, koju su stvarali i ovi autori kao profesori u franjevačkim kolegijima u Dalmaciji na početku 18. stoljeća« (Raguž 1980-1981:97). 
Prema Vinjaliću sedmi padež izriče sredstvo, način i prateću okolnost, ${ }^{34}$ s tim da uvodi normativnu napomenu kako se pri izricanju načina i prateće okolnosti uvijek navodi i prijedlog s' ili sa (iđem sa štapom, s' Petrom, Vinjalić 1809:3). U navedenim primjerima primjetno je kako Vinjalić ispravno i prema pravopisnim načelima rabi oblik prijedloga $s$ ili $s a .{ }^{35} \mathrm{U}$ primjerima štapom (prema lat. cum baculo) i udriti štapom kojima izriče sredstvo ne navodi prijedlog. Osmi padež izražava stanje u mjestu i dolazi uvijek s prijedlogom $u$ (jest pukotina u štapu, Vinjalić 1809:3). ${ }^{36}$

$\mathrm{S}$ obzirom na to da se $\mathrm{u}$ deklinaciji imenica oslanja na latinski jezik, koji je polazni u primjerima, za opis i u paradigmama za jedninu i množinu navodi se samo šest padeža (nominativ, genitiv, dativ, akuzativ, vokativ, ablativ).

Slijedi opis deklinacija za sva tri jezika. Slaveni imaju tri deklinacije koje se prepoznaju prema nastavku genitiva ili ablativa jednine, ${ }^{37}$ pa tako I. deklinacija završava nastavkom -a (Petar, Petra, od Petra; otac, oca, od oca), II. deklinacija nastavkom -e (Mater, Matere, od Matere) i III. deklinacija nastavkom -i (smrt, smrti, od smrti). ${ }^{38}$ Imenice se uvode pokaznom zamjenicom ovaj, koja funkcionira kao oznaka roda, a takva je praksa zabilježena već u Della Bellinoj, ${ }^{39}$ Lanosovićevoj gramatici $^{40}$ i poslije u Voltićevoj gramati$\mathrm{ci}^{41}$ (Gabrić-Bagarić 2008:118).

Nakon kratkih deklinacijskih pravila, slijedi pravilo za konjugaciju glagola. Za hrvatski jezik Vinjalić navodi tri konjugacije, a vrsta konjugacije

$34 »$ Il caso settimo esprime instrumento, modo o concomitanza«. Concomitanza u prijevodu znači istodobno postojanje, sjedinjenje te se može protumačiti kao 'društvo, pratnja ili prateća okolnost' (v. Talijansko-hrvatski ili srpski rječnik, s. v. concomitan$z a, 193$. str.). J. Jernej opisujući Della Bellinu gramatiku navodi kako »Sedmi pak padež odgovara funkcijama današnjega instrumentala (sredstvo, način, popratna pojava, uzrok)«, s tim da u bilješci uspoređuje Della Belline talijanske nazive instrumento, modo, concomitanza (isto kao i Vinjalić) s Kašićevim latinskim nazivima (concomitantia, causa, modo, instrumentum) (Jernej 1991:25).

35 Zapisani kao s' ili sa (Vinjalić 1809:3).

36 Dakle, riječ je o lokativu. "L'ottavo caso dei Slavi esprime stato in luoco« (Vinjalić 1809:3).

37 Sam Vinjalić navodi da su oblici tih dvaju padeža isti (Vinjalić 1809:5).

38 Takvu podjelu imaju također Kašić i Lanosović (1776.) (Tafra 1993:81). Današnje latinske gramatike uzimaju G mn. kao orijentir (Tafra 1993:81). U hrvatskoj je gramatičkoj tradiciji takvo načelo zadržano sve do Vebera.

39 Riječ je o gramatici zapisanoj unutar rječnika Dizionario Italiano, Latino, Illirico, naslovljenoj Instruzioni grammaticali della lingua illirica. Venecija, 1728.

40 Riječ je o gramatici Neue Einleitung zur slavonischen Sprache. Osijek, 1778.

41 Riječ je o gramatici naslovljenoj Grammatica Illirica i zapisanoj unutar rječnika Ričoslovnik iliričkoga, italijanskoga i nimačkoga jezika. Beč, 1803. 
određuju se prema nastavku za 1. lice jd. prezenta, a ne prema nastavku za infinitiv. ${ }^{42}$

Odmah nakon dosta sažetih uvodnih pravila, navode se paradigme za deklinaciju imenskih riječi: imenica, pridjeva, zamjenica, dok su brojevi ${ }^{43}$ obrađeni nakon poglavlja o glagolima.

Dakle, osnovna je koncepcija gramatike sljedeća: gramatička su pravila iznesena na prvim stranicama gramatike nakon čega slijede deklinacijske paradigme imenskih riječi i konjugacijske paradigme za glagole. Sve ostale "normativne" upute sažeto se iznose pod naslovom avvertimento. ${ }^{44}$ Takve normativne upute ili pojašnjenja većinom se odnose na morfologiju, a rjeđe su fonološke napomene kao ona na 105. stranici, gdje se donosi uputa o izgovoru grafema $<$ ç> (fonem /č/) uz usporedbu s izgovorom s talijanskim /z/. Čak su i napomene o slovima na početku poglavlja Rudimenta izrazito sažete, sastoje se samo od komentara kako se slova (littere) dijele na vokale i konsonante, a za ostalo se treba konzultirati Emmanuelov Vocabulario per li principianti. Slavenska abeceda slijedi nakon latinske i talijanske uz napomenu da ju je izumio Konstantin Filozof te da svako slovo ima svoje ime, dakle, riječ je o prikazu glagoljske abecede.

\section{Opis hrvatskoga jezika u gramatici}

Tema je ovoga rada opis hrvatskoga jezika kao samo jedne od sastavnica koja se u gramatici opisuje. Provest ćemo analizu hrvatske sastavnice na fonološkoj, morfološkoj i leksičkoj razini. Na sintaksu ćemo se osvrnuti u onoj mjeri u kojoj je ona u gramatici opisana. Hrvatski se leksik navodi u primjerima te $u$ raznim popisima riječi.

\section{Grafija}

Rukopisna gramatika zapisana je neujednačenim latiničkim pismom, tako da je većina grafema višeznačna. Fonemi se tako označuju jednoslovima, dvoslovima i troslovima.

42 Prvoj konjugaciji pripadaju glagoli kojima infinitiv završava na -ati, a prvo lice prezenta ima nastavak - am. Drugoj konjugaciji pripadaju glagoli tipa štijem, a trećoj konjugaciji glagoli tipa ljubiti. Detaljnije se pojašnjenje ne može vidjeti jer je rukopis oštećen.

43 Iznimku čini deklinacija broja dva i obadva, koja se navodi u sklopu deklinacija imenica i pridjeva jer uz njih autor deklinira i brojevne pridjeve dvoje i oboje (dva, dvi, dva vel dvoje; obadva, obedvi, obadva, vel oboje) (Vinjalić 1809:22).

44 Tako upute u svojoj gramatici naslovljava i Della Bella (Gabrić-Bagarić 2006:133). 
Martina Kramarić: Prilog istraživanju hrvatske sastavnice rukopisne gramatike Principi... FILOLOGIJA 74(2020), 17-48

\begin{tabular}{|c|c|c|c|}
\hline fonemi & grafemi & fonemi & grafemi \\
\hline$|c|$ & $c_{\zeta} \quad c ̧ C \zeta \quad z \quad z z^{45}$ & $/ l /$ & gl gli glj $l i^{46}$ \\
\hline$|\check{c}|$ & $c z c ̧ \quad c ̧ c^{47}$ & $\left|n^{\prime}\right|$ & $g n g n i g n j$ \\
\hline$|c ́|$ & chj chi ch & $|s|$ & $S s S$ \\
\hline $\lg /$ & $g$ & $|\check{S}|$ & SS $S$ \\
\hline $\mid h /$ & $h$ & $|u|$ & $u$ \\
\hline$|i|$ & $i$ ii $i j^{48}$ & $|v|$ & $v f u^{49}$ \\
\hline$|j|$ & $i j$ & $|z|$ & $3 s z$ \\
\hline$|k|$ & $k c h c$ & $|\check{z}|$ & $x s^{50}$ \\
\hline$|d|$ & $g i g g h j^{51}$ & $|f|$ & $f$ \\
\hline
\end{tabular}

Tablica 1. Prikaz Vinjalićeva grafijskog sustava

Slogotvorno /ro / u pisanju zapisuje se skupom ar i skupom er: karv, çarkva, varstee, parvo, pervi, cetuerti, na erpe, razverchi, berso, smerdechia, tverdoglavo, nesverseno, tako da ostaje upitna njegova interpretacija u transkripciji. S obzirom na to da se u gramatici mogu uočiti čakavske i štokavske jezične značajke, a takav je i leksički sloj, te da zapisivanje slogotvornoga $/ \mathrm{r} /$ nije jednoznačno, skloniji smo interpretaciji da je Vinjalić slogotvorno $/ \mathrm{r} /$ izgovarao kao /r/, ali zbog duga tradiciji ipak ga zapisuje uz vokal.

Zasebno tumačenje iziskuje također i bilježenje refleksa jata, fonema /i/ $\mathrm{i} / \mathrm{j} /$ te sljedova /ji/ i /iji/, što je u primjeru starih tekstova zapisanih neujednačenom grafijom često uz fonološki i grafijski problem.

Fonem /i/ piše se trima načinima, kao $<\mathrm{i}>,<\mathrm{ii}>$, $<\mathrm{ij}>$, od kojih su posljednja dva načina rezervirana vjerojatno za oznaku dugoga $\bar{i}$ ( $t i j h$ vel tizij ( $t \bar{i} h$ il $i$ tizì); kijh, kijm (kīh, kìm), ovizii (ovizī), krachiih (kraćīh), obijhdviu (obīhdviju)).

Grafijski skup <ij> može se čitati i kao /ji/, kako je to u primjerima 1. 1 . mn. ličnih i odnosnih zamjenica (moij, moje, moja (moji, moje, moja); tvoij, tvoje, tvoje (tvoji, tvoje, tvoja); koij (koji), koijh (kojih)). Iznimku čini zamjenica čiji, gdje slijed <ij> znači /iji/: cijh (čijih) te komparacija pridjeva: nauçnij (naučniji), priliçnij (priličniji), cestitij (čestitiji).

\footnotetext{
45 U primjeru otazza. higliada.

47 U primjeru troiçça.

48 Za dugo $\bar{\imath}$.

49 U primjeru cetuerti.

50 U primjeru uvjesbati.

51 U primjeru meghju, moguće i pogreškom.
}

46 Vjerojatno pogrešno u izdvojenome primjeru hiliada, inače je uobičajeni zapis 
Martina Kramarić: Prilog istraživanju hrvatske sastavnice rukopisne gramatike Principi... FILOLOGIJA 74(2020), 17-48

Grafemom $<\mathrm{i}>$ zapisuje i fonem /j/: potaino (potajno), siajno (sjajno), naipria (najprija), ali i slijed /ji/: izvan obiçai (izvan običaji).

Skup <ie> može značiti skup /je/ (nesviesno (nesvjesno)), ali i skup /ije/ $\mathrm{u}$ broju nijedan, koji je jednom zapisan tim dvoslovom (niedan), a jednom i troslovom nijedan. S obzirom na zapisani troslov koji podrazumijeva izgovor ije, primjere sa zapisanim dvoslovom <ie > također bismo protumačili kao/ije/ u nastavačnim morfemima (kao u primjeru kraćijeh (krachieh), dobrijeh (dobrieh), ali i u korijenu riječi (bijesno (biesno), smiješno (smiesno)). Međutim, tu nije kraj grafijskoj neujednačenosti Vinjalićeva pisma. ${ }^{52} \mathrm{~S}$ obzirom na to da je primjer pridjeva dobrijeh $\mathrm{u} G \mathrm{Gd}$. zapisan kao dobrieh, a $\mathrm{u}$ Abl jd. (za koji sam Vinjalić navodi da ima isti oblik kao genitiv, Vinjalić 1809:5) dobrjeh, možemo pretpostaviti i u tome slučaju izgovor grafijskoga slijeda <je> kao /ije/. ${ }^{53}$ Tom je analogijom i primjere kao kratkjeh, gliutjeh moguće protumačiti kao kratkijeh, ljutijeh. ${ }^{54}$ Iako nije riječ o nastavku, i u primjeru bio, bjel, bjela, trebali bismo skup je tumačiti kao /ije/ (bio, b(i)jela, $b(i) j e l o$ ) mada dopuštamo i mogućnost jednosložnoga izgovora zbog utjecaja dubrovačkih gramatičara, najvjerojatnije Della Belle. ${ }^{55}$ Međutim, u slučaju posvojne zamjenice moj, G ili Abl mn. moijh vel mojeh transkribirali bismo kao mojih ili mojeh, kako je to također navedeno u Della Belle (Gabrić-Bagarić 2006:51). Iako je Della Bella Dubrovčanin, što podrazumijeva zasebno tumačenje refleksa jata, i Vinjalić kao ikavac vjerojatno je bio nesiguran u zapisivanje izgovora zamjene jata, pa je bio pod utjecajem dubrovačke literature, pisaca i gramatičara. I Della Bella slijed <ij> rabi za/iji/,

52 Upravo zbog grafijske nedosljednosti i nemogućnosti da se ona ispravno protumači bez dvojbe Tafra predlaže zapisivanje izvornim slovopisom kako je to zapisano u rukopisu jer »Ikavsko-jekavsko dvojstvo hrvatskoga književnoga jezika riješeno je tek u doba narodnoga preporoda « (Tafra-Košutar 2012:47). S obzirom na to smatramo da se i naša predložena rješenja promatraju u tom kontekstu, a za svaki oblik navodimo i izvornu grafiju.

53 I Mikalja se također služio skupom <ie> i <je> ravnopravno, pa i u značenju /ije/ (Gabrić-Bagarić 2011:XII).

54 Takav zapis <je> mogao je Vinjalić uočiti u Della Bellinoj gramatici za padežne nastavke u L mn. za pridjevsko-zamjeničku deklinaciju (nepravednjeh, danjeh) iako Gabrić-Bagarić pretpostavlja da je zamjena jata mogla u navedenome padežnom obliku biti dvosložna (Gabrić-Bagarić 2006:141). S obzirom na to da su na Vinjalića utjecali i dubrovački pisci, a vjerojatno i gramatičari, što se vidi u navedenim primjerima koje smo isticali, ne isključujemo mogućnost da se grafemski slijed <je> može u slučaju tih pridjeva interpretirati kao jednosložno /je/. Takav je i slučaj s posvojnom zamjenicom mojeh koja je tako i zapisana. Ipak, zbog teška izgovora kratkjeh, ljutjeh, ali i mogućnosti ugledanja na druge izvore, takvu ćemo grafiju pretpostaviti za dvosložan izgovor jata te zapisivati kao kratkijeh, ljutijeh.

55 Vidi tumačenje o zamjeni jata u Della Bellinoj gramatici (Gabrić-Bagarić 2006:141). 
/ji/ i fonem /i/ (isto:138). Isto se tako i dvoslov <je> mora protumačiti kao /ije/ u primjeru grafije jeptinje (jeptinije) ako nećemo govoriti o jotiranome obliku jeptine.

Vinjalić obično ne bilježi intervokalno /j/: (ogriati (ogrijati), bia (bija), biah (bijah), naipria (najprija), stiau (štijau), dviu (dviju), meu (meju), koigod (kojigod), troiçça (trojica), ali katkad se i bilježi kao u primjeru sajedno (zajedno). Grafem $<j>$ zapisan je na mjestu fonema /j/ u zamjenicama ja, njoj, ${ }^{56} \mathrm{koja}$, koje, moj, tvoj, ${ }^{57}$ prezentu glagola biti (jest i njegovi oblici: jesam, jesu ...), glagolu kajati se, obliku čujem itd.

Razumljiva je neujednačenost i nesigurnost s obzirom na zapisivanje kratke i duge zamjene jata u slučaju Vinjalića kao rođenoga ikavca. Također se njegova neujednačena grafija može protumačiti i ugledanjem na različite izvore.

\section{Fonološka razina}

Odraz jata otkriva nam da je autor pri ekscerpiranju primjera bio pod utjecajem čakavskih i štokavskih ikavskih govora te štokavske ikavske književnosti, ali i štokavske, ijekavske, dubrovačke književnosti. Tako je odraz jata neujednačen i u korijenu riječi, gdje većinom prevladava ikavski odraz (rič, vrime, kolino, lip, pivalica), ali i u nastavcima, gdje je situacija puno kompliciranija. Nastavačnim je morfemima, naime, Vinjalić želio predočiti širu dijalektalnu sliku hrvatskoga jezika te stoga namjerno uvodi nastavačne dublete, ponajprije u pridjevsko-zamjeničkoj deklinaciji. ${ }^{58}$ Ta se intencija proteže u cijeloj gramatici, a posebno je vidljiva u morfološkim značajkama, o čemu će poslije biti riječi.

Tako se pridjev bijel navodi kao bio, bijela, bijelo, a prilog bijesno, glagoli vidjeti, uvježbati, trjeskovati, zasjeći, pripovijesti zapisani su s (i)jekavskim refleksom. Čak se i ekavski refleks uočava u primjerima za brojevne riječi (obadva, obedvi; obadvaju, obeduju) te u glagolu iskorenuti i navesku -ěr u veznicima nuder, deder. Isti navezak na drugome mjestu ima ikavski ostvaraj kakogodir. Očit je utjecaj dubrovačke književnosti u primjeru pripovijesti. U prilozima i prijedlozima prevladavaju ikavski nastavci: najpri, najposli, posli, malo pri, ali uz dubletu ovde/ovdi. Prefiks prě- u obliku je pri- (primnogo, privele, prilipiti, prisuditi, privatiti, prihiniti), što je također odlika i dubro-

\footnotetext{
56 Graf. gnoj.

57 Zamjenica svoj zapisana je $\mathrm{s}<\mathrm{i}>($ svoi).

58 M. Moguš istaknuo je kako »(...) pripadnost se nekom sustavu ne određuje prema leksičkim morfemima nego prema gramatičkim « (Moguš 1969:271-272).
} 
vačke književnosti, gdje se pojavljuje kao okamenjeni ikavizam (GabrićBagarić 2006:141).

Za nastavačne morfeme množinskih padeža uvode se većinom dublete koje Vinjalić pod utjecajem latinske gramatike povezuje veznikom vel ('ili'), a to se odnosi na sve primjere u gramatici. Ista je pojava latinskoga veznika vel u gramatikama pisanima talijanskim jezikom već primijećena i u drugih hrvatskih gramatičara (primjerice Della Bella, Gabrić-Bagarić 2006:133). Nastavci su za genitiv (i ablativ) te dativ ikavski i/ili (i)jekavski (kratkīh vel kratkijeh, dobrīh vel dobrijeh, ljutih vel ljutijeh). ${ }^{59}$ Za dativ se u navedenim primjerima navodi češće samo ikavski oblik (kratkim, kraćim, ljutim) iako ni to nije pravilo pa imamo primjere kao dobrim vel dobrijem.

Što se tiče zamjenica, nastavačni morfemi množinskih su padeža samo ikavski (ovih, ovizih, ovim; tih, tizi, tizim; onih, onizi, onim; kojih, kojizih, kojim; ...), dok se u slučaju množinskih padeža posvojne zamjenice moj uočavaju i jekavski oblici (mojih, mojeh, mojim, mojem). Primjetna je i hiperijekavizacija u primjeru G i Abl jd. kraćijega, D jd. kraćijemu. Za glagole u osnovi riječi uz većinski ikavski refleks (pivati, uvižbati, izmišati, sliditi, virova$t i$, dospiti), pojavljuje se i refleks jekavski (hotiti vel hotjeti, trjeskovati) i ijekavski (pripovijesti). Zanimljiv je ijekavski nastavak u oblicima glagola štiti (štijem, štiješ, štije).

Ekavski je nastavak potvrđen u brojevima: obadva, obedvi; obadvaju, obeduju (uz ikavske kose padeže obihdviju, obimdvima). Ikavske su i zamjenice (ki uz koji, kojigodi, niki, od kijih), oblici brojeva (dvi hiljade).

\section{Završno -1}

Završno - $l$ vokalizirano je, pa tako glagoli biti i moći imaju oblike bio, mogao (mogla, moglo) ali i čuja, otija (ja se čuja, ja otija), što se može protumačiti utjecajem narodnoga govora.

\section{Čuvanje glasa /h/}

Ta je jezična značajka nedosljedno provedena. Glagol htjeti uvijek je zapisan bez inicijalnoga - $h$, kao i glagol oditi (hoditi), početno $h$ - i završno - $h$ također se često gube i u drugim riječima (odma, otimice, itro, ervaski, ercegovina), iako se u nekim slučajevima primjećuju i dublete sa zapisanim glasom /h/ (hitro, bez stra, ali sa strahom). U aoristnim i imperfektnim oblicima također nije usustavljeno zapisivanje glasa $/ \mathrm{h} /$ : bih, bijah (ali bio bi ja, oni bijau bili), bijamo, bijate, bijahu; ja čuh, mogoh; ja mira (gl. miriti), ja činja (činiti), ja iđo (vjeroj. za iđoh) itd. Očito glas /h/ nije pripadao organskomu Vinjali-

59 Tumačenje o grafiji i zapisivanju refleksa jata vidi u prethodnome poglavlju. 
ćevu govoru pa ni nije siguran u njegovo zapisivanje, ${ }^{60}$ a neujednačenost $u$ zapisivanju glasa /h/ značajka je i franjevačkih bosanskih pisaca, iz čijih je djela moguće Vinjalić ekscerpirao primjere. ${ }^{61}$ Skup $<\mathrm{hv}>$ zamijenjen je glasom /f/ u riječi hvala (s praznom falom), što je najvjerojatnije utjecaj bosanskoga govora (Gabrić-Bagarić i dr. 2011:985). Kao utjecaj dijalekta također se tumači i zamjena etimološkoga /f/ glasom /p/ u primjeru jeptinije (isto).

Jotacije

Ni jotacije nisu usustavljene pa se pojavljuju dvostruki oblici, čakavski i štokavski jedan uz drugi: meju (meu), među (meghju), takojer (takojer), također (takogier), slaji (slaji), slađi (slagi).

Za glagol ići potvrđeni su trostruki oblici iđem, idem, gredem, ali za 2. i 3. 1. potvrde su samo u obliku iđeš, iđe, aorist $i đ o$, dakle s provedenom tercijalnom jotacijom, vjerojatno prema dubrovačkome utjecaju. ${ }^{62}$ Izvedenice su od toga glagola također jotirane: pođi ti (poigi ti), ići ćeš ti (ichichies ti), poći ćeš ti (poichichies ti), otići (otichi), ali za lat. venio potvrđeni su i glagoli dohoditi (dooditi), prihoditi (prioditi), vjerojatno prema ugledu na tipične oblike iz renesansne književnosti (Vulić 2016:237). Prilog tja nije jotiran kao ni komparativ pridjeva sladak (slaji).

Jotacija je potvrđena i u oblicima glagola veliti: ja velju, ${ }^{63}$ ti veljaše, te $\mathrm{u}$ imperfektu glagola nositi (ja nošah) i ljubiti (ja ljublja) te u komparativima pridjeva kraći (krachi), slađi (slagi), čak i u obliku ponižan (ponixan) i u pridjevu zdravljiv (zdravgliv). Također je provedena u imenicama građanin, građanka (gragianin, gragianka).

Sekundarna je jotacija u drugoj polovici 18. st. već provedena u govoru, ali i pismu, tako da i Vinjalić jednako zapisuje rezultat prve i sekundarne jotacije, i to najčešće trigrafima $g n i, g n j, g l i, g l j,{ }^{64}$ rjeđe dvografom $g n$ i gl (klagnati se, proklignati, zacignati, bgluvati (bljuvati), nepomglivo, sumgliti, gliubiti, daglje, zazarglieniti se (zacrljeniti se), zemgliu, popgljuvati, napridnje, sversiti govoregne). Ista je situacija i s apstraktnim imenicama tvorenim sufiksom -bje (veseglia).

60 To se može potkrijepiti primjerima kao meghju (među), thio sam (tio sam ili htio sam), othio (otio), gdje je grafem $<$ h $>$ pogrešno zabilježen ili na pogrešnome mjestu.

61 Gabrić-Bagarić (2003:137) kao jednu od značajka zajedničke franjevačke koiné dalmatinskih pisaca 17. i 18. navodi neujednačenosti u bilježenju glasa /h/.

62 Također i u primjeru na početku gramatike u opisu padeža naveden je primjer s jotiranim oblikom glagola ići: iđem sa štapom (Vinjalić 1809:3).

63 Uporaba nastavka -ju za 1. lice prezenta knjiški je utjecaj (Gabrić-Bagarić-Horvat 2008:150) i obilježje franjevačke književnosti (Gabrić-Bagarić 2003:137).

64 I u navedenim su primjerima grafemi $<\mathrm{i}>\mathrm{i}<\mathrm{j}>$ izjednačeni kako smo to već pokazali u radu. 
Ne uočavaju se kolebanja u zapisivanju odraza št/šć, odnosno ostvaraj je uvijek /št/ (godište, šta, pošten), što pridonosi štokavskoj usmjerenosti ove gramatike, također vjerojatno pod utjecajem dubrovačke književnosti. Promjena sekundarnoga skupa -čt- u -št- zabilježena je u primjeru glagola štiti (čitati): štiven, štije.

Neprovedena je metateza zabilježena jednom u primjeru zamjenice sav: vas, sva, sve / vas, sta, ste (deklinacija za lat. tutto). Primjer vapijućega Vinjalić vjerojatno preuzima iz nabožne književnosti.

Potvrđena je i disimilacija u obliku sumljiti $(n j<l j)$, što je zajednička osobina čakavskih i štokavskih govora.

Ne provodi se ispadanje dočetnoga suglasnika - $t$ (milost, kripost), osim u primjeru jedenaes hiljada, ${ }^{65}$ a također se ne uočava pojednostavljivanje skupine -stn- iako ni to nije dosljedno (prilog korisno bilježi kao mnogo koristno ili korisno), dok se skupina -dsk- pojednostavljuje ispadanjem fonema /d/ (pridjev ljudski bilježi se kao gliuski (ljuski)).

$\mathrm{S}$ obzirom na to da se fonem /z/ može zapisivati i grafemom $<\mathrm{s}>$ kao u primjeru sajedno, blisu, nismo sigurni u tumačenje Vinjalićeva provođenja obezvučenja i bilježenje te promjene. Uočeni su primjeri u kojima bi se grafem $<\mathrm{s}>$ mogao tumačiti i kao fonem /s/: bes maskare (bres maskare), bres karvi (bres krvi) i bres načina (bres nacina) uz oblik brez načina (brez nacina). Daljnji su primjeri bez obezvučenja brez sta, brez mire, brez stete, brez uvida, brez pokoja, dubleta bresobrasno/brezobrasno, vasda/vazdi. U slučaju prefiksa češće suglasnik ostaje zvučan izdaleka, izvan, issarca, uz zapis razżbludno, mada se pojavljuju i primjeri kao raskosno.

Prva su i druga palatalizacija provedene: proroci, Božji.

Prezent glagola moći zapisan je obama oblicima, kao možem, ali i s provedenom promjenom $\check{z}>r$ morem, što se također tumači kao adrijatizam (Lisac 2009:17). Oblik samo s provedenim rotacizmom je deder. Provođenje rotacizma karakteristično je već za hrvatske glagoljske tekstove iz 15. i 16. st., ali i za novoštokavski ikavski dijalekt (Šimić 2018). Veznik deder odraz je utjecaja narodnoga govora.

\section{Morfološke značajke}

Morfološke značajke u Vinjalićevoj gramatici nije moguće pratiti preko navedenih primjera ili u popisu riječi na kraju gramatičkoga dijela jer nije zabilježen dovoljan broj slobodnih rečenica. Stoga ćemo morfološki

65 Glavni i redni brojevi redom su u opisu pravila zapisani sa sufiksom -naest, dok je ovdje riječ o primjeru, pa se stoga i uočava iznimka od navedenoga pravila. 
Martina Kramarić: Prilog istraživanju hrvatske sastavnice rukopisne gramatike Principi...

FILOLOGIJA 74(2020), 17-48

pregled ograničiti na deklinacijske paradigme imenskih riječi koje Vinjalić navodi. Dok su u fonološkim oblicima zabilježene nenamjerne dublete, tj. nisu zapisani dubletni oblici jedan do drugoga, ali očituju dvonarječnu autorovu podlogu, štokavsku i čakavsku, u prikazu morfoloških oblika autor gramatike namjerno zapisuje dva ili više oblika s obzirom na različit fonološki ili leksički ostvaraj (dublete ili triplete). ${ }^{66}$

\section{Imenice (Vinjalić 1809:4-16)}

Imenice dijeli na 5 deklinacija prema latinskome modelu, a od padeža navodi N, G, D, A, V, Abl. Ablativ je u obliku jednak genitivu. Tom se padežnom paradigmom koristi u navođenju primjera jer tako latinski jezik određuje padeže. U opisu padeža pak navodi kako Slaveni imaju 8 padeža. Ablativ se u hrvatskim gramatikama zadržao sve do 19. st., a izražavao se kao genitiv s prijedlogom od (Tafra 1993:79). ${ }^{67}$ Tek su ilirske gramatike ustalile paradigmu od 7 padeža. Vinjalić ima isti broj padeža u jednini i množini iako to nije slučaj kod svih dopreporodnih gramatičara, ${ }^{68}$ i to stoga jer se u prikazu padeža drži latinskoga modela, a ne hrvatskoga. Dakle, Vinjalić prikazuje latinsku paradigmu s hrvatskim primjerima, što je u skladu s cijelom koncepcijom gramatike.

Od nastavaka izdvojit ćemo u G mn. nastavak - $a$, koji u zapisu naglašava dvostrukim aa: ovizii govoregnaa, ovizii prorokaa, ovizii vrimenaa, danaal dnevaa, otaçaa i materaa, ovizii kolenaa. ${ }^{69} \mathrm{G}$ mn. s nastavkom -a morfološka je inovacija štokavskoga narječja, koju Vinjalić prihvaća i propisuje svojom gramatikom. Međutim, bilježenje dvostrukoga aa značajka je koju je Vinjalić mogao uočiti u Kašića, Della Belle ili u starijoj dubrovačkoj književnosti. ${ }^{70}$ Za razliku od Della Belle i Kašića, Vinjalić ne spominje mogućnost

66 Morfološka sinonimija obilježje je hrvatskih ranih gramatika, a obilato je potvrđena već u Kašića (Tafra 1993:81).

67 Pregled o tome koje gramatike prikazuju ablativ, a koje sedam ili osam padeža, ovisno o broju imenice, uključujući i kajkavske gramatike, vidi u Štebih Golub (2014:19).

68 O tome vidi u Tafra (1993:80).

69 Primjere donosimo u izvornome zapisu kako bi se i vidjelo načelo zapisivanja dvaju grafema $<\mathrm{a}>$ umjesto dugoga $\bar{a}$. Iznimku čini imenica gospodin zapisana s jednim $<\mathrm{a}>$ (ovizii gospodina).

70 Prema istraživanju Ham, Della Bella je jedini od starijih gramatičara koji je tako bilježio dužinu za nastavak u G mn. (Ham 2006:28-29). Mi smo takvu značajku uočili i u Kašića (vojvodaa). Autorica u svojemu kronološkom pregledu hrvatskih gramatika ne navodi Vinjalićevu gramatiku niti o njoj raspravlja u studiji. Tim primjerom, a i drugim primjerima koje smo uočili u opisu Vinjalićeve gramatike, potvrđuje se teza Gabrić-Bagarić o tome kako su Kašićeva i Della Bellina gramatika »diktirale i određivale gramatikološke i gramatičarske postupke velikomu broju mlađih autora jezičnih 
Martina Kramarić: Prilog istraživanju hrvatske sastavnice rukopisne gramatike Principi... FILOLOGIJA 74(2020), 17-48

nultoga nastavka u G mn. (isto:28).

Za D mn. Vinjalić navodi nastavke -om/-em za muški ili srednji rod: dnevom, prorokom, gospodinom, ovom govorenjem; dok je jednom za sr. r. vjerojatno pogreškom uveden nastavak -am (ovizim oćućenjam). Za ženski je rod potvrđen nastavak u D mn. -am (crkvam), a u paradigmi za $i$-vrstu -im (ovim milostim).

Imenica dan zapisana je i u mlađemu i u starijemu obliku, ali samo u množini, dok je u jednini deklinacija samo jedna, osim $u$ akuzativu. Pripada V. deklinaciji, također naravno prema latinskome modelu: N dan, G i Abl dneva, D dnevu, A dan/dneva; $\mathrm{N}$ mn. dni/dnevi/dneve, G mn. danaa/dnevaa, $\mathrm{D}$ mn. dnevom, A mn. dneve, $\mathrm{V}$ mn. o dni/dnevi, Abl mn. danaa. Vinjalić iznosi napomenu kako je imenica dan iznimka iz I. hrvatske deklinacije. Imenica gospodin ima u množini dubletne oblike N mn. gospodini // gospoda, G mn. gospodina // gospode.

Pridjevi (Vinjalić 1809:16-21)

Vinjalić ne razlikuje određeni i neodređeni vid, odnosno opisuje samo zamjeničku deklinaciju, ${ }^{71}$ a takva je situacija u hrvatskim dopreporodnim gramatikama već od Kašića pa do Voltića (Tafra 1993:94) zbog ugledanja na latinski jezik. Oblik Petrov spominje se samo u normativnoj napomeni o izricanju posvojnosti koju smo već prikazali, te se spominje u sintaktičkome kontekstu, a ne u morfološkome, i zabilježen je samo u nominativu. Tako je i u ostalih gramatičara u 17. i 18. st. ako uopće registriraju neodređene oblike (Gabrić-Bagarić 2003:74).

U množinskim padežima supostoje nastavci za ikavske i ijekavsku varijantu, primjerice G i Abl mn.: kraćijeh, kraćih/ljutih, ljutijeh/kratkih, kratkijeh/dobrih, dobrijeh, dobrim, dobrijem, o čemu smo već raspravljali u poglavlju o grafiji. U primjeru čestitih, čestitim, te u dativu kraćim, ljutim, kratkim zabilježen je samo ikavski odraz jata.

U D jd. pridjeva bilježi se nastavak -om s naveskom -u, a za lokativ naveske ne navodi jer je taj padež prema latinskome modelu ablativ, pa ne znamo za Vinjalićev stav o navesku u lokativu. Nastavci za D i L jd. u hrvatskome jeziku ujednačuju se od 15. st. (Tafra 1993:98), a prema primjerima u popisu riječi vidimo da Vinjalić za L jd. navodi nastavak - $u$, tj. da su oblici za D i L ujednačeni. Također je primjetna uporaba naveska -u za

priručnika« (Gabrić-Bagarić 2008:159).

71 Prema Tafri trebalo bi se govoriti o imeničkoj i zamjeničkoj deklinaciji, a ne o određenome i neodređenome pridjevu jer je kategorija određenosti u pridjeva samo dijelom morfološka oznaka (Tafra 1993:96). 
lokativ jednine: $u$ onomu/tomu mistu, na drugomu mistu. Također ćemo u istim primjerima uočiti čakavsku osobinu uporabe akuzativa umjesto lokativa uz prijedloge $n a, p o, u$ u primjerima: na četorto misto, $u$ isto misto, $u$ svako misto.

Vinjalić navodi vokativ jednine za pridjeve koji je isti kao nominativ, osim u slučaju pridjeva isti, drugi, čija se paradigma navodi unutar opisa zamjenica. Navođenje vokativa pridjeva nije inače u hrvatskoj gramatikološkoj praksi uobičajeno (Tafra 1993:99).

U stupnjevanju pridjeva zastupljeni su suvremeni oblici. U slučaju zločest, gori, najzločestiji uporaba leksema zločest za zao leksičko je pitanje. Uvodi i prefiks pri-kao jednu od mogućnosti izražavanja superlativa: pri + pozitiv ili naj + komparativ: velik, privelik, najveći. Takvu tvorbu superlativa s pri-, odnosno elativa, uveo je Kašić, a preuzeli su ga u svojim gramatikama Della Bella, Appendini, ${ }^{72}$ Jurin, ${ }^{73}$ Lanosović (Štebih Golub 2014:28) (malahan, manji, primalahan, najmanji; slatki, slaji, prislatki, najslaji; jak, jači, prijak, najjači; dobar, bolji, pridobar, najbolji).

\section{Zamjenice}

Lične zamjenice (Pronomina Primitiva) (Vinjalić 1809:22-23)

U opisu ličnih zamjenica ${ }^{74}$ zabilježeni su različiti oblici, mlađi i stariji, a u množinskim nastavcima zabilježena je samo ikavska varijanta, osim u primjeru posvojne zamjenice moj, za koji se navode dublete (G, Abl mojih (moijh), mojeh (mojeh)).

Za lične zamjenice $m i$ i vi u D mn. navode se mlađi (nam, vam), ali i stariji oblici vami, nami. U slučaju D mn. zamjenice oni navodi se noviji oblik njima uz njim. S obzirom na to da se ne navodi instrumental u paradigmi, ne znamo je li autor imao namjeru zabilježiti proces ujednačivanja množinskih padeža i primanja dvojinskih nastavaka. U lične zamjenice uvrštava i zamjenicu sebe (to je oblik za genitiv, nominativ se ne navodi), a uz nju navodi se oblik svoj, svoja, svoje (samo u nominativu). Očito je da je Vinjalić shvaćao zamjenicu se kao povratno-posvojnu, ali to je pogrešno izvedeno. ${ }^{75}$

72 Riječ je o gramatici Grammatica della lingua Illirica. Dubrovnik, 1808.

73 Riječ je o gramatici Slovkinja slavnoj slovinskoj mladosti đačkim, iliričkim i talijanskim izgovorom napravljena. Venecija, 1793.

74 S obzirom na dvojnost u nazivlju, osobne i lične zamjenice, koristimo se nazivom lične prema Markoviću (2012:320).

75 Da je i drugim gramatičarima bio problem određivanje vrste zamjenice se i svoj, vidi u Tafra (1993:109-110). 
Martina Kramarić: Prilog istraživanju hrvatske sastavnice rukopisne gramatike Principi... FILOLOGIJA 74(2020), 17-48

Pokazne zamjenice (Pronomina Demostrativa [sic!]) (Vinjalić 1809:23-26)

Pokazna zamjenica ovaj ima oblike ovi, ova, ovo, a taj to. U pokazne zamjenice uvrštava i 3. lice ličnih zamjenica: on, ona, ono // oni, one, ona uz isti. Zamjenicu on svrstao je Vinjalić u pokazne kao oblike zamjenice onaj pod utjecajem latinske gramatike, a tako je već navedeno u Kašića, Della Belle, pa i poslije u Appendinija (Tafra 1993:113). Hrvatsku inačicu lične zamjenice on, ona, ono donosi tako kao ekvivalent čak trima latinskim oblicima (ille, illa, illud / ipse, ipsa, ipsum / is, ea, id), a stoga u deklinaciji koja se uz varijacije ponavlja triput donosi uz lične i posvojne oblike (za G jd. njegov, njezin, G mn. njiovo), a kao ekvivalent latinskoj pokaznoj zamjenici ille, illa, illud navodi oblike pokazne zamjenice onaj u skraćenome obliku on vel oni prema dubrovačkome utjecaju (Gabrić-Bagarić-Horvat 2008:147). Takav oblik pokazne zamjenice u množini dobiva navezak -zi, kao i pokazne zamjenice ovi, ti, te odnosna zamjenica koji: onizi, ovizi, tizi, kojizi. Navezak -zi u množini iz dubrovačkoga je govora i književnosti, ali je prisutan i u bosanskim književnim tekstovima (Turbić-Hadžagić 2014:196). ${ }^{76}$

Oblik N jd. za pokaznu zamjenicu ovaj je samo ovi, što je također utjecaj dubrovačke književnosti i govora (Gabrić-Bagarić-Horvat 2008:147). U jednini se navodi samo tvrda promjena ovoga, ovomu, dok se u množini navode oblici u kosim padežima s naveskom -zi i oni bez naveska -zi (ovih, ovizih). Za 2. lice pokazna je zamjenica taj, ta, to: G mn. tih, tizi; D mn. tim, tizim: $\mathrm{G}$ i Abl mn. zapisani su bez dočetnoga $-h$, što nije iznimka u gramatici.

Posvojne zamjenice (Pronomina Derivativa) (Vinjalić 1809:26-27)

Posvojna zamjenica moj jedina u G jd. ima kratki i dugi oblik (moga, mojega), dok zamjenica tvoj ima samo kratki oblik (G m. r. tvoga, ž. r. tvoje). Zamjenica moj također jedina ima zapisan prikaz množinskih padeža, koji su dubletni (mojih, mojeh; mojim, mojem). Posvojni oblici njegov, njezin i njiovo za treće lice navedeni su kao genitivni jedninski i množinski oblici u paradigmi za promjenu zamjenice on, ona, ono; isti (prema latinskome ipse, ipsa, ipsum, i u mn. za G mn. eorum, earum, eorum), a tako je i u gramatici Della Belle, koji ih prvi uvodi, doduše također uz pokazne zamjenice, ali bez oblika njezin. Kašić i Mikalja uopće ne navode oblike za 3. lice, a Šitović i Babić navode ih uz lične zamjenice uz G i napomenu da genitivi »zlamenuju posjedovanje (Gabrić-Bagarić 2003:74). Takva pojava jasna je jer se u književnosti još u 18. st. posvojnost izricala genitivom ličnih zamjenica nje,

76 Autorica ih je uočila u bosansko-humskim poveljama pisanima od 12. do 15. stoljeća, i to onima koje su nastale na području Bosne, a izostavila je u proučavanju one koje su nastale $u$ Dubrovniku. 
Martina Kramarić: Prilog istraživanju hrvatske sastavnice rukopisne gramatike Principi...

FILOLOGIJA 74(2020), 17-48

njih, a takve primjere navodi i Zima u analizi jezika dubrovačkih autora, Palmotića i Gundulića (Zima 1887:198).

Zamjenice Pronomina tertia [sic!] declinationis (Vinjalić 1809:27)

Kao te zamjenice Vinjalić navodi pridjeve našinski i vašinski (uz imenicu našinac te pridjeve vaški ili vaši). To nije slučaj u svih gramatičara te tako Gabrić-Bagarić (2008:119) primjećuje da Della Bella navodi samo pridjev našinski, dok Voltiggi po uzoru vjerojatno na Lanosovića dodaje i paralelu vašinski. Vinjalić donosi paralelu vašinski, ali s napomenom kako taj oblik nema vokativ te da je općenito rijetko u uporabi i odlika je narodnoga govora (Vinjalić 1809:27). Inače su takve stilske napomene rijetka pojava u Vinjalićevoj gramatici.

Odnosne zamjenice (Pronomen relativum) (Vinjalić 1809:28)

Zamjenicu koji Vinjalić navodi kao odnosnu, a za ženski rod navodi samo skraćene oblike, čakavske $k a, k e, k u$, osim u D jd., gdje bilježi oblike prema obliku koja (koj ili kojoj). Oblik koga u G jd. za muški i srednji rod smatra se preuzimanjem genitiva zamjenice $t k o$, a to je već uočeno i u Mikaljinoj gramatici (Gabrić-Bagarić-Horvat 2008:147). U množini dolaze i oblici s naveskom -zi (za G mn. kojih, kojizih, te čijih).

Upitne zamjenice (Provocabulum interrogativum) ${ }^{77}$ (Vinjalić 1809:28)

Zamjenica tko navodi se kao upitna: tko? ka? što?, s tim da je za ženski rod naveden čakavski oblik zamjenice koja ( $k a$ ?). U jedninskim padežnim oblicima za muški rod ne dolazi do pojednostavljenja suglasničke skupine te se navode oblici tkoga, tkomu, od tkoga. Za srednji rod funkcionira zamjenica što s genitivom čigov, zapisana u sva tri roda (G jd. tkoga, ke, čigov, čigova, čigovo) ${ }^{78}$ a riječ je o preuzimanju dubrovačkoga oblika nastala od oblika njegov (Gabrić-Bagarić-Horvat 2008:147). ${ }^{79}$ Također se kao upitne zamjenice navode i čakavski sažeti oblici ki? ka? ka? te zamjenica šta? (G jd. kih, čiji, čija, čije), koja otkriva da je Vinjalić vjerojatno štakavac i da svoju gramatiku piše prema štokavskoj standardizaciji.

Ostale zamjenice navodi kao composita, među kojima se nalaze različiti oblici složenih zamjenica, od kojih neki i nisu zamjenice, nego frazeologizirani izrazi (kigodi, tkogodi, kojigod, jedakoji, da ne bi koji, ako koji, svaki koji, koji mu drago, koji oćéš).

77 Autor ne objašnjava promjenu naziva za zamjenice (pronomen/provocabulum).

78 Oblike navodimo prema tomu kako ih Vinjalić zapisuje iako su zapisani nasumično bez obzira na vrstu i padež zamjenice.

79 Detaljnije pojašnjenje o tome vidi u Skok II:110, s. v. ko. 
Martina Kramarić: Prilog istraživanju hrvatske sastavnice rukopisne gramatike Principi...

FILOLOGIJA 74(2020), 17-48

Neodređena zamjenica neki ima samo ikavski oblik: niki, nika, niko. Neodređena zamjenica kojigod ima i oblik s naveskom -ir: kojigod, kojegod, kojigodir, kojagodir.

Zamjenica sav ima samo u N jd. oblik bez provedene metateze: vas, sva, sve vel vas, sfa, sfe (samo je grafijska razlika) za lat. totus.

Brojevi (Vinjalić 1809:171-174)

Brojeve dijeli na glavne i redne. Glavni su jedan, jedna, jedno; dva, dvi, dva vel dvoje, tako da se uz dekliciju broja dva donosi i deklinacija za brojevni pridjev dvoje. Zanimljiv je G jd. s oblicima dvaju, dviju vel dvih, a u slučaju deklinacije broja obadva u G jd. uočavaju se ikavski i ekavski oblici (obadvaju, obeduju vel obihdviju). Navode se, dakle, i dvojinski oblici kako je to već navedeno u Kašića, ali i padežni oblici za brojevne pridjeve. Za dativ su navedeni samo ikavski oblici (obimdvima). Broj tri Vinjalić ne deklinira te uz njega zapisuje oblik trojica. Od četiri nadalje također ne deklinira brojeve. Della Bella, primjerice, deklinira brojeve tri i četiri iako navodi da se u nekih autora broj četiri ne deklinira (Gabrić-Bagarić 2006:59). Kolebanja su oko deklinacije brojeva logična jer se brojevi rijetko sklanjaju (Tafra 1993:105). Deklinaciju brojeva dva i obadva uz brojevne pridjeve dvoje, oboje donosi uz deklinaciju zamjenica, a poglavlje o brojevima s podjelom na glavne i redne nakon poglavlja o glagolima.

Brojevi od 10 do 20 tvore se nastavkom -naest. To su stegnuti oblici, a ne stariji dulji tvoreni brojem deset (jedanadesete), koje Vinjalić ponovno uvodi u prikazu rednih brojeva.

U brojeva složenih sa sto piše se svaka znamenka odvojeno: sto $i$ jedan, sto $i$ dva, sto i devedeset $i$ devet. Dvista i trista ikavski su oblici, a četiri stotine Vinjalić piše odvojeno i time ne slijedi navedenu paradigmu. Tako nastavlja i dalje: pet stotina, devet stotina.

Broj 1000 piše kao hiljada ili tisuća, a s primjerima dvi hiljade, jedanaes hiljada Vinjalić pokazuje kako uz broj dva brojevni predmet dolazi u G jd., a uz jedanaest u G mn., kako je i suvremeno stanje.

Za redne brojeve u primjeru brojeva s deseticama Vinjalić miješa starije i mlađe oblike: jedanadesti, jedanaest $i$, dvanadesti, trinadesti vel trinaesti itd. Za broj sto navodi se uz stoti i oblik stotinji (naveden prema AR-u u značenju rednoga broja samo u Vitezovićevu rječniku, v. AR XVI, s. v. stotiníi), a za tisuću hiljadni, vjerojatno prema analogiji od oblika stotinji, prema AR-u (v. AR III, s. v. hiljadni) također uočen samo u Vitezovićevu rječniku.

Vinjalić navodi i oblike za dijelne brojeve (jedan po jedan, dva i dva ili dvi stvari svakomu, svak na pose, četiri po četiri, pet po pet), koji su više sveze s 
brojevnim riječima nego brojevi.

Među brojevnim pridjevima glavnim navode se oblici jednom, jedanput, jedankrat, jednoč, dva puta, dva krat ... hiljada puta, tisuća krat itd., to jest stariji čakavski oblici i noviji štokavski, a među brojevnim pridjevima rednim oblici najprija, prvo, drugo, opet, treće, treći put, četvrto, peto, šesto itd.

Glagoli (Vinjalić 1809:30-171)

Poglavlje o glagolima najopširnije je te je njemu autor posvetio dio od 30. do 171. stranice rukopisa. Na tim je stranicama dan opsežan pregled glagolskih vrsta, vremena, a velik dio te opširnosti prouzročen je time što je autor htio pokazati kako se talijanski konjunktivi mogu prenijeti u hrvatski jezik. Rezultat toga česte su nelogičnosti i nepostojani zabilježeni oblici. Poglavlje o glagolima izostavit ćemo stoga iz ovoga pregleda jer je izrazito opširno i zahtijeva zaseban istraživački rad. S druge strane, s obzirom na potpunu prilagodbu latinskomu i talijanskomu konjugacijskom modelu, mnogi su glagolski oblici nepostojeći pa i nelogični, te su vjerojatno nastali kao rezultat Vinjalićevih prevoditeljskih pokušaja. Tako je Vinjalić, primjerice, zabilježio oblike kao »bivši da sam ja štiven il budući ja štiven, vel budući da se ja štijem, il štijući se ja «a paradigmu glagola čitati (štiti) za Conjunctivi Modi tempus praesens (Vinjalić 1809:83). Spomenut ćemo samo knjiške oblike kao nastavak -ju (ja velju) u prezentu te tvorbu budućega vremena prefiksom uz- (uzčujem, uzbudem) (Gabrić-Bagarić 2006:148). 
Martina Kramarić: Prilog istraživanju hrvatske sastavnice rukopisne gramatike Principi... FILOLOGIJA 74(2020), 17-48

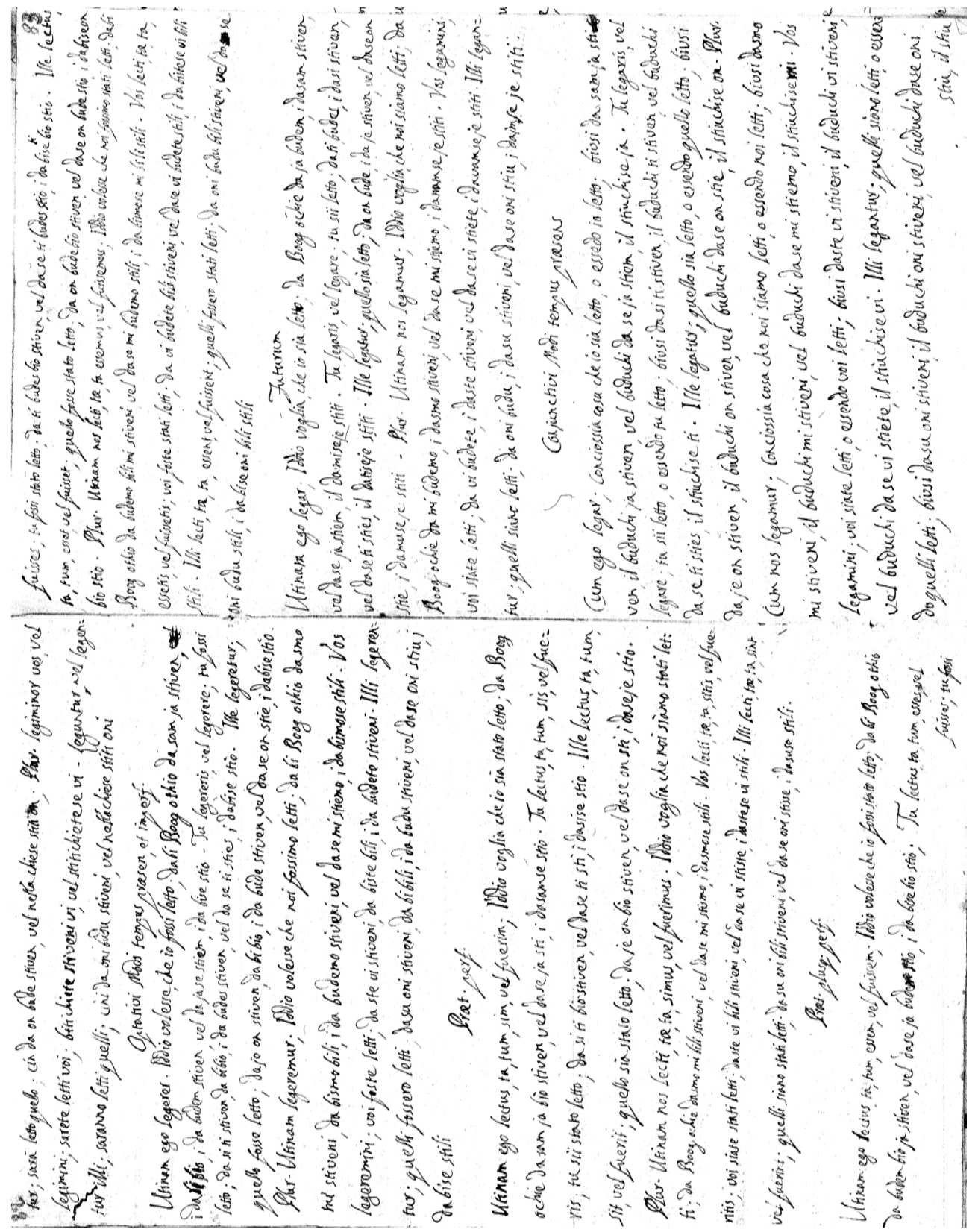

Prilog 2. Snimka stranica 72 i 73 iz rukopisne Vinjalićeve gramatike 
Martina Kramarić: Prilog istraživanju hrvatske sastavnice rukopisne gramatike Principi...

FILOLOGIJA 74(2020), 17-48

\section{Leksičke značajke}

Popisi riječi koji se u Vinjalićevoj gramatici nalaze u poglavlju Rudimenta bogat su izvor za istraživanje leksičkih značajka Vinjalićeva hrvatskoga jezika. Autor u namjeri da svojom gramatikom predstavi narječnu raznolikost hrvatskoga jezika, ali i da ona bude korisna što široj publici, namjerno donosi više sinonimnih riječi u svakoj natuknici, odnosno jednu latinsku riječ prevodi s više hrvatskih riječi. Tako se uporedo donose raznonarječne inačice istoga priloga (mnogo puta, mnogo krat; lipo, krasno; more biti, može biti; mnogo, privele, saviše; s načinom, s razborom; navlastito, napose). Prvo lice prezenta glagola govoriti izražava trima sinonimima: starohrvatskim ja pravim, općim ja govorim i oblikom ja velju, koji očituje utjecaj franjevačke književnosti. Glagol htjeti također je zabilježen dvjema osnovama: hotiti i htjeti. ${ }^{80}$ Očito su mu kao izvor leksika poslužili organski čakavski i štokavski ikavski govori i štokavska ikavska književnost jer su primjeri većinom zapisani s ikavskim refleksom jata. Također primjećujemo utjecaj dalmatinsko-dubrovačke književnosti, u kojoj su se održale neke starije jezične osobine, kao primjerice staroslavenska manira izražavanja vremena akuzativom ${ }^{81}$ (za malo vrime, $u$ koliko vrime, u niko vrime). Prisutan je i leksik dubrovačke književnosti (ponase, pose 'odjelito, posebice', uporaba imenice običaj u ženskome rodu: suprot običaji, izvan običaji), ${ }^{82}$ uz jedan primjer uporabe u muškome rodu ( (činiti žito). Primorskomu leksiku, u kojemu su zastupljeni čakavski i štokavski leksemi, također pripadaju i glagol mučati, prilozi prija, najprija, veznik jur, jurve. Takav je leksik Vinjalić mogao primiti i iz primorske književnosti, kao u slučaju leksema odiliti se, celivati, uzmnožno. Vinjalić uvodi i ustaljene knjiške fraze kao ništanemanje, 83 cića toga, po taj način, ni po jedan način, a uočavaju se i grecizmi (također preuzeti preko književnosti ili iz narodnoga govora): s jasprima, siditi za trpezom ${ }^{84}$ ili turcizmi aramzadno (od

80 U izvornome zapisu to izgleda kao otitti, il otit, il titti, vel othietti. Oblici su glagola od osnove htjeti jotirani (da oće Bog da ja neću), a u obama oblicima glagola ne bilježi se inicijalno $h$ - (ja neti i nisam thio). I u slučaju negiranoga oblika glagola htiti negaciju ne piše zajedno s glagolom (ja nethiah).

81 Ta se osobina uočava i u starohrvatskim glagoljskim tekstovima, primjerice u Zrcalu člověčaskago spasenja (1445.). Vidi Kramarić 2019:110.

82 Vidi AR VIII, s. v. običaj, »U dubrovačkih pisaca običaj je ponajviše ženskoga roda...«.

83 Frazeologizirana sveza ništanemanje, tvorena vjerojatno prema latinskome izrazu nihilominus, prisutna je još od starohrvatskoga književnoga jezika, a susreće se i u primorskim lekcionarima (Barbarić i dr. 2016:86 i AR VIII s. v. ništa).

84 Trpeza je stara grčka posuđenica u hrvatskome jeziku, a jaspra se bilježi od 16 . stoljeća. Detaljnije vidi u Šimić 2016. 
psovke haramzada, 'kopile') u značenju 'lažno, prijetvorno'. Narodni leksik zastupljen je prilogom nadvor (AR VII, s. v. nadvor), zajednička izoglosa u govoru u Poljicima u Dalmaciji i oko Vareša u Bosni, te također prilogom plao (plao srdito), koji se govori u Bosni, prijedlogom oliš (osim), koji se govori u čakavskome i štokavsko-ikavskome dalmatinskome području (AR VIII, s. v. oliš), veznicima deder, nuder, dederte, nuderte. Još jedan oblik koji povezuje bosansku i dalmatinsku književnost, ali ne i dubrovačku (AR XI, s. v. pram, prama), prijedlog je prema naveden uvijek $\mathrm{u}$ obliku pram (pram amo, pram onamo, pram svakomu mistu, pram livoj ruci). Navedeni mogući utjecaj i bosanske franjevačke književnosti ${ }^{85}$ važan je za proces standardizacije hrvatskoga jezika na štokavskoj osnovi, kojega je i Vinjalić bio svjestan. Leksik kao glagoli pripovijesti, osvaditi otkriva i dubrovački utjecaj, također važan u standardizaciji na štokavskoj osnovici. U popisu riječi donosi i ekvivalent za latinski quid?, odnosno za zamjenicu što, koji su šta i ča. Postavljanje štokavskoga oblika prije čakavskoga također dosta govori o autorovoj štokavskoj usmjerenosti u pisanju ove gramatike, a činjenica da se navodi štakavski dijalektalni oblik puno govori o utjecaju narodnoga jezika na autora.

\section{Zaključak}

Iako je Vinjalićeva gramatika Principi della grammatica [...] Grammatica prima in lingua slava, italiana et latina pisana s namjerom da čitatelje podučiti hrvatskomu, latinskomu i talijanskomu jeziku, gramatika pripada redu hrvatskih gramatika koje su pisane prema latinskome modelu i s latinskim kao polaznim jezikom. Prikaz hrvatskoga jezika sužen je tako na primjere kojima se donose latinske jezične paradigme, ali i na dosta bogat popis riječi na kraju gramatike. Ono što nedostaje jest slobodan tekst u kojemu bi se lakše mogle uočiti jezične značajke Vinjalićeva hrvatskoga jezika. U primjerima smo uočili kako autor donosi raznonarječne oblike, štokavske i čakavske, ikavske i ijekavske, ali ne propisuje koji bi oblik trebao imati prednost. ${ }^{86}$ Stoga ovu gramatiku može-

85 Uočeni bosanski leksik prisutan je i u Divkovićevu djelu Besjede Divkovića svrhu evanđel'ja nedjeljnijeh priko svega godišta (1616.). Vidi poglavlje o leksiku u Barbarić i dr. (2016:80-92).

86 Što se tiče pitanja Vinjalićeva normiranja, ponavljamo i citiramo Tafru, koja navodi kako je u leksikografskim i gramatičarskim djelima do 19. st. glavno obilježje »(...) dubletnost i na leksičkom i na gramatičarskom planu. Naime, književnojezična norma koju pratimo preko gramatičara dopušta morfološku i leksičku sinonimiju, koja je rezultat međunarječne konvergencije na višoj, iznaddijalektalnoj razini, u nekih autora više ili manje prisutnih « (Tafra 2012:396). U tome kontekstu Tafra nastavlja kako su sve predstandardne hrvatske gramatike »(...) ujedno i opisivale i propisivale« (isto:397). 
mo smatrati nasljednicom Kašića, koji je također na isti način navodio odgovarajuće oblike iz obaju narječja, odnosno opisivao je »čakavsko-što kavsku književnu koiné«, s tim da je štokavski oblik često navodio kao prvi (Stolac 2004:35). ${ }^{87}$ U Vinjalićevu slučaju ne može se pratiti zbog mnoštva primjera koji se od oblika navodi prvi, štokavski ili čakavski, ali se u presezanju značajka štokavskoga narječja u opisu hrvatskoga jezika može tvrditi kako svoju gramatiku piše u okviru standardizacije na štokavskoj osnovici. To se uočava i u posezanju za brojnim primjerima iz dubrovačke književnosti, ali i govora, posebice u morfološkim oblicima. Najbrojniji su tako uočeni utjecaji u zamjeničkoj deklinaciji (oblik čigov, navezak -zi, oblici za prvo lice oni, ovi). Uz dubrovačku, uočili smo utjecaje i primorske književnosti, ali i bosanske franjevačke književnosti, zbog kojih i pretežu štokavski ikavski oblici. ${ }^{88} \mathrm{Uz}$ ikavizme uočili smo i (i)jekavizme, pa čak i ekavizme, čime se očituje Vinjalićeva namjera za sveobuhvatnim opisom hrvatskoga jezika. Uporedo uz književne uočeni su i razgovorni oblici, a takav je slučaj i s drugim hrvatskim gramatičarima iz 17. i 18. stoljeća (Gabrić-Bagarić 2003:72). Prema svemu navedenome, možemo reći kako gramatika slijedi onodobnu hrvatsku gramatikološku tradiciju, a izdvaja se presloženim opisom glagolskoga sustava. Gramatika nije tiskana, pa vjerojatno stoga ni nije zaživjela u uporabi dalje od samostanskih zidova, iako svakako zaslužuje znanstvenu pozornost jer je riječ o prvoj trojezičnoj franjevačkoj gramatici. Prema Jerneju ta je gramatika i talijanskoga jezika ispunila prazninu nakon Mikaljine gramatike (1649.) u razdoblju od 1650. pa sve do 1800. godine i poslužila kao uzor za Jurinovu gramatiku Slovkinja slavnoj slovinskoj mladosti đačkim, iliričkim i talijanskim izgovorom napravljena (1793.) (Jernej 1981:176-177). ${ }^{89}$ Dodatnu vrijednost gramatici daju bogat onomastički popis i opis hrvatskoga, ponajprije dalmatinskoga, ali i bosanskohercegovačkoga geografskog područja, te navedeni povijesni podatci povezani s tim područjem.

87 Stolac stoga smatra da se Kašićeva gramatika ispravno navodi kao čakavsko-štokavska u popisu tiskanih hrvatskih gramatika koji Tafra donosi u svojoj knjizi (2003:181).

88 »Još od Kašića i Mikalje (17. st.) u južnim se hrvatskim krajevima ikavska štokavica ustalila kao koiné sna kojoj će se pisati sve knjige na području Bosne Srebrene sve do početka 19. st.« (Demo 2004:45). Toj tvrdnji dodali bismo samo i čakavski sloj koji je ta književnost također sadržavala.

89 Prema Jerneju riječ je ipak o latinskoj gramatici pisanoj hrvatskim jezikom »koja na str. 394-422. pod naslovom »De vocabulis domesticis« sadrži i stvarni trojezični rječnik latinsko-talijansko-ilirski, a na str. 423-459. kratku hrvatsku gramatiku na hrvatskom jeziku« (Jernej 1981:177). 


\section{Građa}

Vinjalić, Gašpar. 1809. Principi della grammatica ad uso de Slavi che desiderano esser Religiosi con quali apprenderano nell' istesso tempo la Lingua Latina ed Italiana, servirà anco agli Italiani per apprender la Lingua Slava. Opera di Fra Gasparo Vignalich ex Diffinitor dell' Osservante Provinzia dell Santissimo Redentor in Dalmazia. Grammatica prima in lingua slava, italiana et lati$n a$ (rukopis). Franjevački samostan u Sinju. Sign. I./2.

\section{Literatura}

$\mathrm{AR}=$ Rječnik hrvatskoga ili srpskoga jezika. I-XXIII. Zagreb: Jugoslavenska akademija znanosti i umjetnosti, 1880. - 1975.

Barbarić, Tadija i dr. 2016. Besjede fra Matije Divkovića. Zagreb: Institut za hrvatski jezik i jezikoslovlje.

Belić, Aleksandar. 1999. Istorija srpskog jezika: fonetika, reči sa deklinacijom, reči sa konjugacijom. Beograd: Zavod za udžbenike i nastavna sredstva.

Deanović, Mirko; Josip Jernej. 1980. Talijansko-hrvatski ili srpski rječnik. Zagreb: IRO »Školska knjiga«.

Demo, Šime. 2004. Latinska sintaksa kao implicitno prisutna problematika u gramatikama Tome Babića i Lovre Sitovića. Fluminensia, 16, 1-2, 45-63.

Gabrić-Bagarić, Darija. 1989. Jezik Ivana Bandulavića, bosanskoga franjevca 17. vijeka. Sarajevo: Svjetlost.

Gabrić-Bagarić, Darija. 2002. Život i djelovanje Bartola Kašića (1575. 1650.). Ur. Znika, Marija. Institutiones linguae Illyricae. Osnove ilirskoga jezika (pretisak). Prijevod s izvornika: Sanja Perić Gavrančić. Pogovor: Darija Gabrić-Bagarić. Zagreb: Institut za hrvatski jezik i jezikoslovlje, 385-431.

Gabrić-Bagarić, Darija. 2003. Jezik u gramatikama južnih hrvatskih prostora 17. i 18. stoljeća. Rasprave Instituta za hrvatski jezik i jezikoslovlje, 29, 65-86.

Gabrić-Bagarić, Darija. 2006. Ardelio Della Bella - gramatičar. Ur. Znika, Marija. Instruzioni grammaticali della lingua illirica (Gramatičke pouke o ilirskome jeziku) (pretisak). Prijevod s izvornika: Nives Sironić-Bonefačić. Pogovor: Darija Gabrić-Bagarić. Zagreb: Institut za hrvatski jezik i jezikoslovlje, 127-151.

Gabrić-Bagarić, Darija. 2008. Grammatica Illirica Josipa Voltiggija (1803.). Rasprave, 34, 115-131.

Gabrić-Bagarić, Darija; Marijana Horvat. 2008. Gramatika talijanska ukratko (1649.) Jakova Mikalje. Ur. Znika, Marija. Gramatika talijanska ukrat- 
ko ili kratak nauk za naučiti latinski jezik (pretisak). Transkripcija: Marijana Horvat. Popratna studija i tekstovi: Darija Gabrić-Bagarić i Marijana Horvat. Zagreb: Institut za hrvatski jezik i jezikoslovlje, 105-168.

Gabrić-Bagarić, Darija i dr. 2011. Jakov Mikalja. Blago jezika slovinskoga (1649./1651.). Transkripcija i leksikografska interpretacija. Zagreb: Institut za hrvatski jezik i jezikoslovlje.

Gulin, Ante. 2011. Prikaz knjige Gašpar Vinjalić, Kratki povijesni i kronološki pregled zbivanja koja su se dogodila Slavenima u Dalmaciji, Hrvatskoj i Bosni 1514.-1769., preveo, dodao podnaslove i uputnice na vrela Bruno Pezo, uskladio s izvornikom i popratio objašnjenjima Vicko Kapitanović, Književni krug, Split 2010., 287 str. Zbornik Odsjeka za povijesne znanosti Zavoda za povijesne $i$ društvene znanosti Hrvatske akademije znanosti $i$ umjetnosti, 29, 397-400.

Ham, Sanda. 2006. Povijest hrvatskih gramatika. Zagreb: Nakladni zavod Globus.

Jernej, Josip. 1981. Povijest talijanskih gramatika na hrvatskom ili srpskom jeziku od 1649. do 1900. Rad JAZU, 388, 131-236.

Jernej, Josip. 1991. Struktura Della Belline gramatike. Filologija, 19, 23-29.

Kapitanović, Vicko. 2010. Vinjalić, Gašpar Petar. Hrvatska enciklopedija, mrežno izdanje. Leksikografski zavod Miroslav Krleža. http://www.enciklopedija.hr/natuknica.aspx?id=64749 (pristupljeno 12. 4. 2019.).

Kramarić, Martina. 2019. Zrcalo člověčaskago spasenja (1445.). Transkripcija, kontekst nastanka i jezičnopovijesna analiza. Zagreb: Institut za hrvatski jezik i jezikoslovlje.

Lisac, Josip. 2009. Hrvatska dijalektologija 2. Čakavsko narječje. Zagreb: Golden Marketing.

Marković, Ivan. 2012. Uvod u jezičnu morfologiju. Zagreb: Disput.

Marković, Ivan. Hrvatske gramatike. Popis hrvatskih gramatika Zagrebačke slavističke škole. http://wwww.hrvatskiplus.org/article.php?id $=1760$ Enaslov $=$ hrvatske-gramatike (pristupljeno 12. 4. 2019.).

Matasović, Ranko. 2008. Poredbenopovijesna gramatika hrvatskoga jezika. Zagreb: Matica hrvatska.

Moguš, Milan. 1969. Jezični elementi Držićeva "Dunda Maroja". Zbornik radova o Marinu Držiću. Ur. Ravlić, J. Zagreb: Matica hrvatska, 269-281.

Perić Gavrančić, Sanja. 2015. Lanosovićev prinos izgradnji hrvatskoga jezikoslovnog nazivlja. Ur. Samardžija, Marko. Hrvatski jezik i pisana riječ XVII. i XVIII. stoljeća. Zbornik radova. Vinkovci: Privlačica d. o. o., $56-60$.

Raguž, Dragutin. 1980./1981. Hrvatska gramatička terminologija u dvjema preradbama Alvaresove latinske gramatike. Filologija, 10, 97-125. 
Skok, Petar. 1971. - 1974. Etimologijski rječnik hrvatskoga ili srpskoga jezika IIV. Zagreb: JAZU.

Stolac, Diana. 2004. Metodološki problemi u istraživanju sintakse u starim hrvatskim gramatikama. Fluminensia, 16, 1-2, 31-43.

Stolac, Diana. 2009. Gramatika Lovre Šitovića u kontekstu hrvatske gramatikologije. Ur. Knezović, Pavao. Zbornik radova sa znanstvenoga skupa »Lovro Šitović i njegovo doba«. Zagreb: Hrvatski studiji Sveučilišta u Zagrebu, 129-136.

Šimić, Marinka. 2018. O jeziku Politike za svakog čovika fra Petra Bakule. Ur. Ševo, Ivan. Zbornik o fra Petru Bakuli o 200. obljetnici njegova rođenja, Znanstveno-stručni simpozij, Mostar 2016. Mostar: Fram-Ziral, 282-318.

Štebih Golub, Barbara. 2014. Ignacije Szentmártony i Uvod u Nauk o horvatskome jeziku. Ur. Horvat, Marijana. Ignacije Szentmártony, Uvod u Nauk o horvatskome jeziku (pretisak). Prijevod: Barbara Štebih Golub. Popratna studija: Barbara Štebih Golub. Zagreb: Institut za hrvatski jezik i jezikoslovlje, 1-64.

Tafra, Branka. 1993. Gramatika u Hrvata i Vjekoslav Babukić. Zagreb: Matica hrvatska.

Tafra, Branka. 2012. Obilježja hrvatske gramatičke norme do kraja 19. stoljeća. Ur. Holzer, Georg. Prinosi povijesti hrvatskoga jezikoslovlja. Zagreb: Hrvatski studiji Sveučilišta u Zagrebu, 394-405.

Tafra, Branka; Petra Košutar. 2012. Novoštokavska obilježja hrvatskoga književnoga jezika u 17. stoljeću. Ur. Holzer, Georg. Prinosi povijesti hrvatskoga jezikoslovlja. Zagreb: Hrvatski studiji Sveučilišta u Zagrebu, 3953.

Turbić-Hadžagić, Amira. 2014. Deklinacija neličnih zamjenica u bosansko-humskim poveljama s posebnim osvrtom na zamjenice s navescima: $-z i,-r /-r e$ i -i. Filologija, 63, 193-221.

Vinjalić, Gašpar. 2010. Kratki povijesni i kronološki pregled zbivanja koja su se dogodila Slavenima u Dalmaciji, Hrvatskoj i Bosni 1514.-1769. Preveo, dodao podnaslove i uputnice na vrela Bruno Pezo, uskladio s izvornikom i popratio objašnjenjima Vicko Kapitanović. Split: Književni krug.

Vinjalić, Gašpar Petar. Hrvatska enciklopedija. Zagreb: Nakladni zavod Miroslav Krleža. http://www.enciklopedija.hr/natuknica.aspx?id=64749 (pristupljeno 12. 4. 2019.).

Vlastelić, Anastazija. 2007. Sročnost u hrvatskome jeziku u gramatici fra Lovre Sitovića Ljubušaka. Ur. Vranić, Silvana. U službi jezika. Zbornik u čast Ivi Lukežić. Rijeka: Filozofski fakultet u Rijeci, Odsjek za kroatisti$\mathrm{ku}, 249-266$.

Vulić, Sanja. 2016. Jezična previranja u dubrovačkoj renesansnoj književnosti. Colloquia Maruliana, XXV, 229-258. 
Zima, Luka. 1887. Njekoje, većinom sintaktičke razlike između čakavštine, kajkavštine $i$ štokavštine. Zagreb: JAZU.

A contribution to the research of the Croatian language component of Gašpar Vinjalićs manuscript grammar

Principi della grammatica [...] Grammatica prima in lingua slava, italiana et latina

\begin{abstract}
This article presents an unpublished, little-known grammar Principi della grammatica [...] Grammatica prima in lingua slava, italiana et latina. Originally written in the mid-18th century, it has survived only in an 1809 transcription. The grammar is trilingual and written according the Latin grammar model and under the influence of Manuel Álvares. Examples for the Latin paradigms are also written in Italian and Croatian. The subject of this article is the description of the Croatian component of this grammar. The Croatian language of Vinjalić's grammar is based on the Ikavian and (I)jekavian speeches of the Štokavian dialect and the Čakavian dialect. The examples mentioned were extracted from literature from Dalmatia, Dubrovnik, and Bosnia, as well from the vernacular. The article pays special attention to the morphological description of nouns. It also compares this Franciscan grammar with other grammars written prior to 1800 , as well as with the tradition of the grammatical description of the Croatian language. It is concluded that this grammar follows the tradition of the grammatical description of the Croatian language. Vinjalić's grammar may be relevant to historical and onomastic analysis as it contains a list of toponyms from Croatia and Bosnia and Hercegovina, as well a list of historical events and persons from the same area.

Ključne riječi: predstandardne hrvatske gramatike, franjevačke gramatike, trojezične hrvatske gramatike, štokavsko i čakavsko narječje

Keywords: pre-standard Croatian grammar books, Croatian grammar books, Franciscan grammar books, trilingual Croatian grammar books, Štokavian and Čakavian dialect
\end{abstract}

